\title{
Norwegian margin outer shelf cracking: a consequence of climate-induced gas hydrate dissociation?
}

\author{
J. Mienert $\cdot$ M. Vanneste $\cdot$ H. Haflidason • \\ S. Bünz
}

Received: 28 May 2009/ Accepted: 26 February 2010/Published online: 3 April 2010

(C) The Author(s) 2010. This article is published with open access at Springerlink.com

\begin{abstract}
A series of en echelon cracks run nearly parallel to the outer shelf edge of the mid-Norwegian margin. The features can be followed in a $\sim 60-\mathrm{km}$-long and $\sim 5$-km-wide zone in which up to 10 -m-deep cracks developed in the seabed at $400-550 \mathrm{~m}$ water depth. The time of the seabed cracking has been dated to $7350{ }^{14} \mathrm{C}$ years BP (8180 cal years BP), which corresponds with the main Storegga Slide event $(8100 \pm 250$ cal. years BP $)$. Reflection seismic data suggest that the cracks do not appear to result from deep-seated faults, but it cannot be ruled out completely that tension crevices were created in relation to past movements on the headwall of the Storegga slide. The cracking zone corresponds well to the zone where the base of the hydrate stability zone (BHSZ) outcrops. Evidence of fluid release in the BHSZ outcrop zone comes from an extensive pockmark field. We suggest that post-glacial ocean warming triggered the dissociation of gas hydrates while the interplay between dissociation, overpressure, and sediment fracturing on the outer shelf remains to be understood.
\end{abstract}

Keywords Gas hydrates · Geohazards · Slope stability · Climate change $\cdot$ Norwegian Margin

J. Mienert $(\bowtie) \cdot$ S. Bünz

Department of Geology, University of Troms $\varnothing$,

Dramsveien 201, 9037 Troms $\varnothing$, Norway

e-mail: jurgen.mienert@uit.no

M. Vanneste

Norwegian Geotechnical Institute (NGI) and International

Centre for Geohazards (ICG), 0855 Oslo, Norway

H. Haflidason

Department of Earth Science, University of Bergen,

Allégt. 41, 5007 Bergen, Norway

\section{Introduction}

Outer shelf cracks and elongated depression features were first discovered along a 40-km-long section of the U.S. Atlantic margin (Driscoll et al. 2000; Hill et al. 2004). The individual cracks are several $\mathrm{km}$ long, $1 \mathrm{~km}$ wide and up to $50 \mathrm{~m}$ deep. The cracks and depressions seem to be caused by "gas blow-outs" related to the release of shallow gas. The precise age of the blowouts and the origin of the gas remain unknown; however, they are most likely post-Last Glacial Maximum (LGM). This could indicate that ocean warming triggered methane hydrate dissociation processes. Methane hydrates are an ice-like solid formed by the inclusion of methane in water molecules. They are stable under pressure and temperature conditions found on the mid-Norwegian margin and most of the world's continental margins (e.g. Henriet and Mienert 1998) at depths greater than several hundred metres and low temperatures (e.g. Mienert et al. 2005; Bünz et al. 2009).

More recently, echo sounder surveys provided evidence for gas venting on the outer shelf of the northern Norwegian (Chand et al. 2008) and the W-Svalbard margin (Knies et al. 2004) where hundreds of methane plumes were discovered (Westbrook et al. 2009). The gas flares occur in water depth at $<400 \mathrm{~m}$ that is close to the required depths for methane hydrate stability on the continental shelf. The plumes occur in regions that today fall outside of the temperature-pressure conditions for the stability field of methane hydrates. However, episodic plume activity is observed within deeper waters $(1200 \mathrm{~m})$ and above a gas hydrate reservoir in an active methane venting province offshore NW-Svalbard (Hustoft et al. 2009a). The fact that the gas hydrate outcrop zones of the largest gas hydrate provinces in Europe are on the Norwegian-Barents-Svalbard (NBS) margins makes the U.S. Atlantic margin-Norwegian Atlantic margins response 
of gas hydrate fields to post-glacial climate conditions particularly important for studies of submarine slope failures, gas blowouts or geohazards in general (e.g. Driscoll et al. 2000; Locat and Mienert 2003; Canals et al. 2004; Mienert et al. 2005; Solheim et al. 2005; Mienert 2009).

The NBS margin hosts one of the largest gas hydrate provinces on the European margin (e.g. Mienert et al. 2001; Bünz et al. 2003; Vanneste et al. 2005; Hustoft et al. 2009a, Bünz et al. 2009) (Fig. 1). It is an area where numerous seeps have been documented (e.g. Hovland 2009), and we thus know that gas migration has occurred or takes place continuously in permeable or hydro-fractured layers of sediments (Hustoft et al. 2007; Hustoft et al. 2009a, b). More than 400 pockmarks that are connected to chimneys (columnar disturbances of parallel-bedded deposits) were identified in the Nyegga pockmark field (Hustoft et al. 2009b). The pockmarks are of post-glacial age (18.5-13.2 cal ka BP) based on accelerator mass spectrometry AMS $-{ }^{14} \mathrm{C}$ measurements of planktonic foraminifera and Bathymodiolus clams from inside the depressions (Paull et al. 2005) and pore-pressure modelling results integrated with $3 \mathrm{D}$ seismic data (Hustoft et al. 2009b). Hustoft et al. (2009b) suggested that rapid sedimentation during the last ice age developed the overpressure in contourite and gas-charged sediments in the sub-seabed. When the pore pressure is above the hydrostatic pressure, it may trigger hydro fracturing and pore pressure release and thus fluids may rapidly escape upwards as manifested in the Nyegga pockmark field. The field shows $<15 \mathrm{~m}$ deep and between 70- and 350-m-wide pockmarks in water depths between $630 \mathrm{~m}$ and $800 \mathrm{~m}$ on the continental slope (Figs. 1, 2) that is west of the
Møre-Trøndelag continental shelf (Hustoft et al. 2009b). Further south, the Møre continental shelf is relatively narrow $(<100 \mathrm{~km})$ and its shelf edge is shaped by the giant Storegga Slide event that occurred during the Holocene at $8100 \pm 250$ cal. BP (Haflidason et al. 2004, 2005) while the Trøndelag shelf is wider $(<250 \mathrm{~km})$ and the water depth varies between $200 \mathrm{~m}$ and $600 \mathrm{~m}$.

Further evidence of degassing processes in the Nyegga complex pockmark (G11) comes in the form of authigenic carbonate crusts (Hovland et al. 2005; Mazzini et al. 2006). Geochemical and petrological investigations of crust samples indicate precipitation of methane-derived aragonite. Hovland et al. (2005) suggest that the methane-derived authigenic crusts (MDACs) formed prior to more vigorous fluid flow that formed the G11 pockmark complex (Fig. 2). The complex pockmarks connect to and have their source within the mounded contourite body that occurs approximately $200-400 \mathrm{~m}$ beneath the pockmark field (Hustoft et al. 2009b). The contourite body hosts a regional bottomsimulating reflector (BSR), which marks the boundary of methane hydrate above and free gas beneath it (Bünz and Mienert 2004; Hustoft et al. 2009b). Sampling of pockmarks including G11 has documented the presence of methane hydrate within the upper metre of seabed sediments that suggest ongoing micro seepage of methane (Ivanov et al. 2007; Haflidason et al. 2008).

Major efforts have been placed into the understanding of glaciated margin sedimentary processes (e.g. King et al. 1998; Vorren et al. 1998; Mienert and Weaver 2003), slope instabilities (Bryn et al. 2003; Haflidason et al. 2004, 2008; Mienert 2004; Laberg et al. 2003, 2007) and fluid expulsions that resulted in pockmarks (e.g. Hovland et al. 2005; Hustoft et al. 2009b, Hjelstuen et al. 2009). Following the
Fig. 1 Map of the NorwegianGreenland Sea showing the Nyegga gas hydrate province (encircled A). It refers to the northern flank of the Storegga slide including the Nyegga pockmark field (Hustoft et al. 2009b).The area shows fluid escape features in gas-hydrated sediments. Large submarine slides along the margin are marked (stippled lines) and major known hydrocarbon reservoirs are shown in red (from Hustoft et al. 2009). The narrow Møre shelf lies east of the Møre Basin and the wider Trøndelag shelf northeast of Nyegga

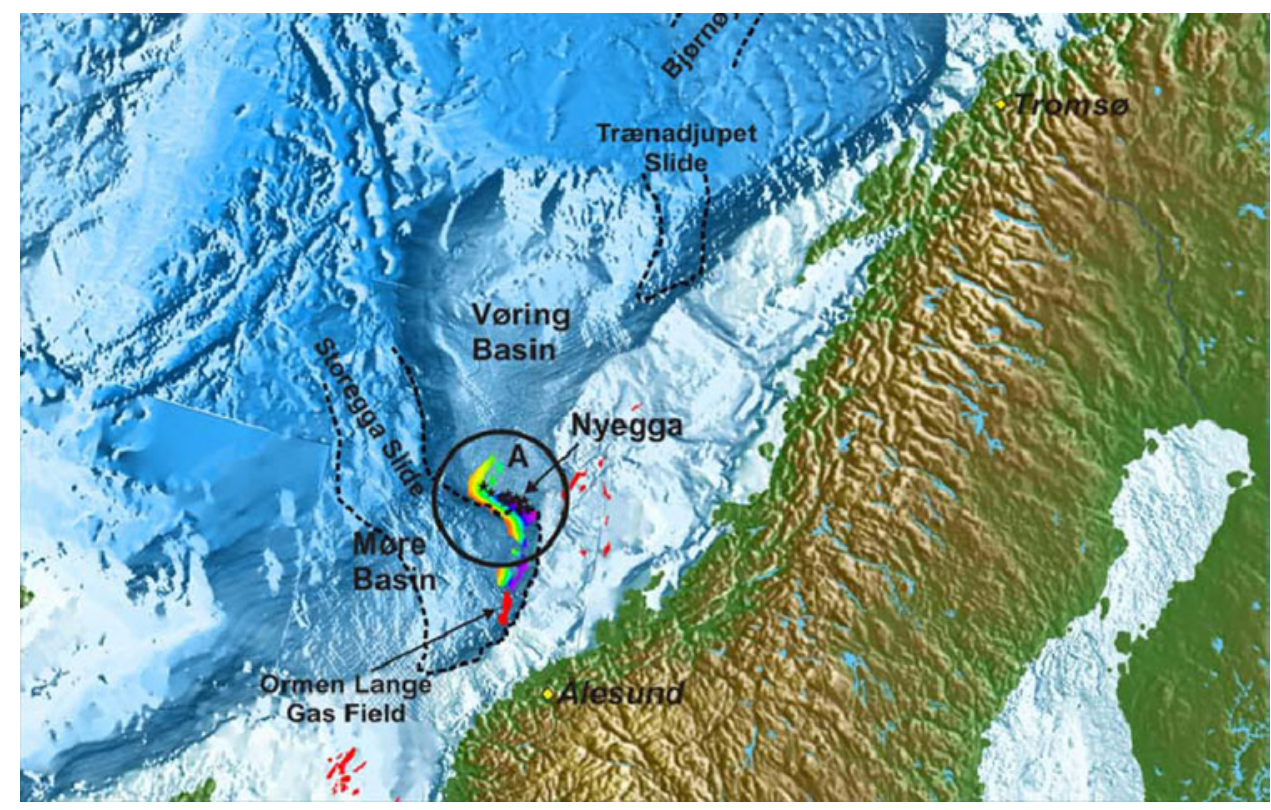


Fig. 2 Merged swath bathymetry data of the Nyegga and northern Storegga slide scar shows the northern sidewall and Storegga slide headwall area.

The northern escarpment has a height of $<100 \mathrm{~m}$ and the headwall a height of $<450 \mathrm{~m}$. The dots mark seabed fluid escape feature depressions (pockmarks CN03 and G11) within the Nyegga pockmarks field (Hustoft et al., 2009) that contained methane-derived authigenic carbonate crusts (MADCs) (Hovland et al. 2005; Mazzini et al. 2006) and gas hydrate crystals (Ivanov et al. 2007). The shelf area (right, red) shows numerous crosscutting iceberg plough marks typically found on formerly glaciated shelves

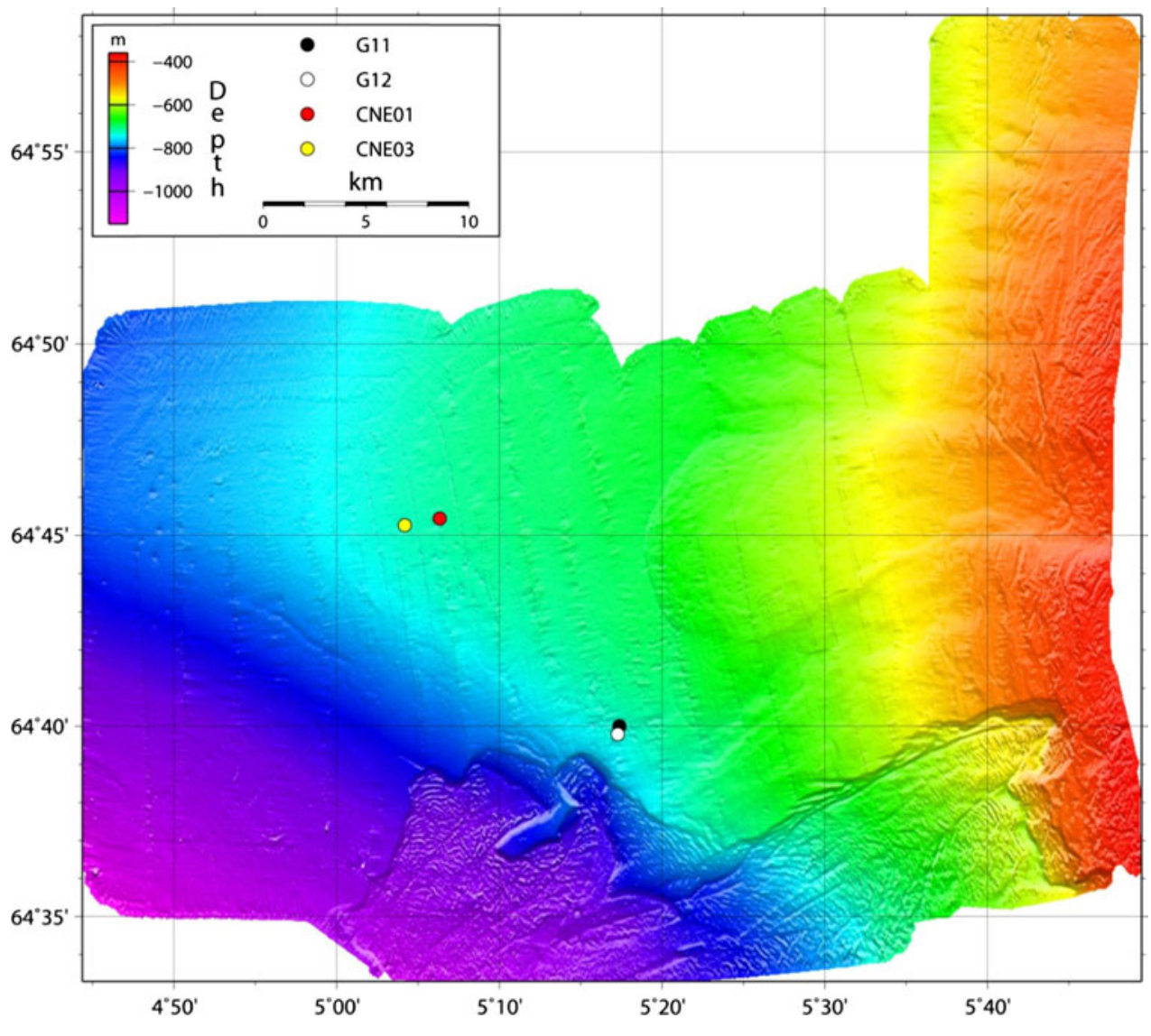

discovery of the Ormen Lange deep-water gas field within the Storegga Slide scar, the Seabed Project started an extensive research in the area (Bryn 1998; Bryn et al. 2005) with large seabed mapping activities (e.g. BritSurvey 1999).

Particular interest arose for the area north of the Storegga Slide when seismic profiles acquired by both academia (e.g. R/V Jan Mayen from Troms $\varnothing$ University) and hydrocarbon industry (BritSurvey 1999) revealed the presence of extensive bottom-simulating reflections (BSR) (e.g. Bugge 1983; Mienert et al. 1998, 2001, 2005; Bouriak et al. 2000; Bünz et al. 2003; Bünz and Mienert 2004; Hustoft et al. 2007).

Geophysical surveys were carried out onboard R/V Jan Mayen to map the BSR and the outcrop zone area on the upper slope and shelf in more detail. A survey consisted in general of single-channel seismic data acquisition, $3.5 \mathrm{kHz}$ echo-sounding, swath bathymetry mapping, CTD profiling on specific target areas and shallow sediment gravity coring. Hydrate stability modelling was carried out using gas hydrate stability programmes (Sloan 1998). Of particular interest was the theoretical outcrop zone of the base of the gas hydrate stability zone (BGHS) and its geophysical proxy (BSR). We present high-resolution swath bathymetry data, single-channel sleeve gun seismic reflection profiles and $3.5-\mathrm{kHz}$ echo-sounder profiles from the projected BSR outcrop zone on the outer shelf. The observations have implications for understanding seabed features, fluid flow escape and gas flares in areas where global warming may influence changes in the gas hydrate outcrop zone on upper continental slopes and shelves at high latitudes such as the Arctic.

\section{Tectonic and geological setting}

Several extensional phases culminated in continental rifting and opening of the NE Atlantic Ocean at the Paleocene-Eocene transition (Skogseid et al. 2000). During the Cenozoic, the passive Norwegian margin has experienced both tectonic events (Talwani and Eldholm 1977) and large-scale sedimentary activity (Vorren et al. 1998). Following break-up, the mid-Norwegian margin was subject to deformation, mainly compressional in origin, which resulted in the development of several $\mathrm{N}-\mathrm{S}$ trending dome structures, attributed to a major change in plate motion in the early Oligocene (Lundin and Doré 2002). Uplift of the Norwegian mainland (Neogene) and Quaternary glaciations has resulted in large-scale shelf progradation (e.g. Evans et al. 1996; Sejrup et al. 2000; Vorren et al. 1998). 
The sedimentary succession includes the shale-prone Brygge Formation (Eocene-Oligocene), fine-grained hemipelagic oozes and clays of the Kai Formation (Miocene-early Pliocene), and contouritic, debris flow and turbidite deposits of the Naust formation (Plio-Pleistocene) (Rokoengen et al. 1995; Rise et al. 2006). 3D seismic data revealed polygonal fault systems in the uppermost Brygge and Kai Formations (Berndt et al. 2003; Hjelstuen et al. 2004). The northern flank of the Storegga area is further characterised by the presence of gas hydrates, shallow gas accumulations and fluid discharge features (e.g. Mienert et al. 1998, 2001; Bouriak et al. 2000; Bünz et al. 2003; Gravdal et al. 2003; Hovland et al. 2005). Widespread pockmarks and mounds have been associated with overpressured free gas below the gas hydrate stability zone (GHSZ) within the Plio-Pleistocene Naust Formation (Bünz et al. 2003; Hustoft et al. 2007; Westbrook et al. 2008; Hustoft et al. 2009b, Bünz et al. 2009; Plaza Faverola et al. 2010).

Plio-Pleistocene progradational wedges of the midNorwegian margin document the glacial-interglacial sediment cycles on the continental slope region. Grounded or fast-flowing ice streams extended to the shelf edge during peak glaciations causing debris flows and major sediment accumulation centres on the slope west of the shelf (Sejrup et al. 2000; Ottesen et al. 2002). It is well documented that during the Plio Pleistocene (last ca. 2.6 Ma) and particularly during the last $500 \mathrm{ka}$ several episodes of major glacier advances took place, reaching the continental shelf (e.g. Vorren et al. 1998; Dowdeswell and Siegert 1999; Sejrup et al. 2000; Dowdeswell et al. 2002; Ottesen et al. 2002; Taylor et al. 2002).

Deposition of fine-grained hemipelagic, glaciomarine, marine and contouritic sediments marks the interglacial periods. During interglacial periods, the northward directed Norwegian Atlantic Current caused contourite build-ups within former slope failure areas, i.e. palaeo slide scars (Bryn et al. 2005; Hjelstuen et al. 2005; Solheim et al. 2005). The contourite bodies may be particularly sensitive to rapid sediment loading (Bryn et al. 2005) as documented by the chimneys and pockmarks above them (Hustoft et al. 2009b).

\section{Data and methods}

\section{CTD profiles}

At two CTD stations (core stations 794 and 796), we measured the variation of temperature, salinity, acoustic velocity, and sigma- $t$ density through $<600 \mathrm{~m}$ of the water column on the outer shelf (Figs. 3a, 4). In addition, we took CTD casts on the lower and upper slope. The average acoustic velocity over the entire water column from these two CTD stations on the shelf is $1485 \mathrm{~m} \cdot \mathrm{s}^{-1}$. Bottom water temperature reaches of $3.06^{\circ} \mathrm{C}$ (water depth $\sim 520 \mathrm{~m}$ ) and $2.06^{\circ} \mathrm{C}$ (water depth $\sim 560 \mathrm{~m}$ ), but minus degrees below approx. $800 \mathrm{~m}$ water depth.

\section{Seismic and bathymetry data}

We recorded a total of $365 \mathrm{~km}$ of seismic data and swath bathymetry data (Figs. 2, 3a) crossing the fault zone along the mid-Norwegian margin.

Echo-sounder data were recorded and stored on a hard disk using the Delph2 recording/processing unit. These data give highly detailed images of the uppermost sediment layers. Single-channel seismic data were recorded in nearly zero-offset mode, by a floating 6-m-long streamer. The double sleeve guns (0.65 1 volume per gun) were towed at $4 \mathrm{~m}$ submersion depth. The guns were fired at pressures of 130-140 bar with a very small triggering time offset (0.2-0.4 ms) between the two guns to minimise the bubble effect. The shot interval was $10 \mathrm{~s}$, giving a spacing of $24.9 \pm 1.9 \mathrm{~m}$. Multi-channel seismic data were made available by the Seabed project (NH9651-109).

Swath Bathymetry is acquired onboard RV Jan Mayen using a Kongsberg Simrad 300 with a $50 \mathrm{~m}$ grid spacing (Fig. 2). This data set covers the main part of the study area on the mid-Norwegian margin between $4-6^{\circ} \mathrm{E}$ and $64^{\circ} 35^{\prime}$ to $64^{\circ} 55^{\prime} \mathrm{N}$. Additionally, Norsk Hydro ASA provided an additional bathymetry data set with $25 \mathrm{~m}$ grid spacing from the sea bed cracking system (Fig. 3a) to create a detailed seafloor relief and dip map (Fig. 3b).

Sediment coring, logging and age dating

Sediment cores were taken to look for evidence for cold seep faunas or seep structures in the seabed crack area (Figs. 3a, 4). Three gravity cores (stations 794, 796, 801) were logged for physical properties using the GEOTEK Multi-Sensor-Core Logger (MSCL). The first two sediment cores (station 794: $5 \mathrm{~m}$ long; and station 796: $4 \mathrm{~m}$ long) were taken in the vicinity of the seabed crack system along the industrial line NH9651-109, and in between the acquired seismic profiles 02JM798 (Fig. 3a) and 02JM799. Core 794 is located slightly upslope the crack zone in water depth of $\sim 540 \mathrm{~m}$ (Figs. 3a, 4) while core 796 lies further downslope of the seabed crack system in water depth of $\sim 580 \mathrm{~m}$ (Fig. 4). The third gravity core (station 801: $4 \mathrm{~m}$ long) was recovered from $\sim 730 \mathrm{~m}$ water depths on top of a potential mud mound (Fig. 5).

Upon recovery, the cores were immediately sealed. The unsplit cores were logged after they reached thermal equilibrium. After the core logging, the three sediment cores were split and scanned for X-ray imagery. The 


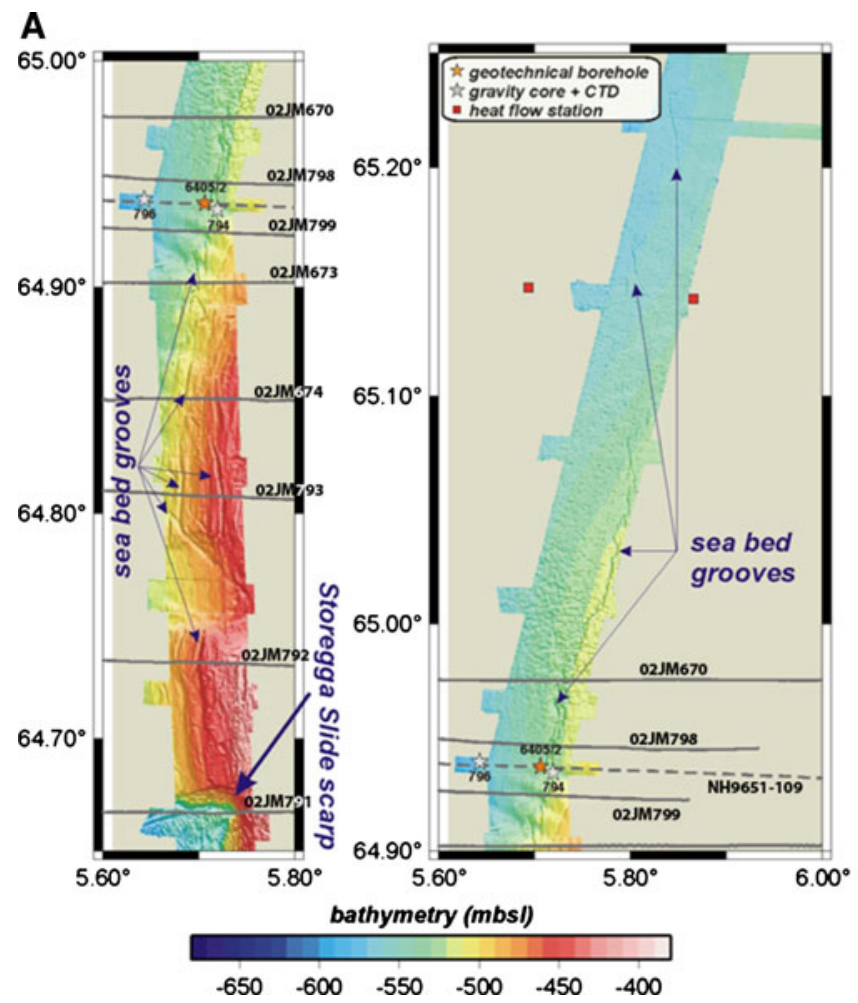

Fig. 3 High-resolution shaded-relief map (a) and seafloor dip map (b) over part of the sea bed cracks north of the Storegga Slide escarpment. (University of Troms $\varnothing$ single channel (SC) seismic data = grey lines $;$ NH line 9651-109 = dashed grey line $).$ The SC line numbers are from top to bottom 09JM679, 798,799,673,674,798

radiographs are used to determine internal structures (e.g. fractures) of the sediment cores that cannot be resolved visually.

Core (NH9856 SPB-003SC) recovered by the University of Bergen (Haflidason et al. 2000, 2005) was used for age dating the cracks and is located near borehole 6405/2-U1 (Fig. 3a, location 122). The core (location 122) is located in the open crack area north of the main Storegga Slide headwall, in a water depth of $525 \mathrm{~m}$ (Figs. 3, 6). The crack system found in this area (Bryn et al. 1998) has been traced into the northern part of the Storegga Slide main headwall. The core with the thickest post-crack sediments has been selected for litho-, bio- and chronological studies. The main purpose of this core investigation is to date the age of these crack features.

Theoretical modelling of hydrate stability conditions

The GHSZ modelling uses a best-fit analytical 3-phase (gas, sea water, hydrate) equation based on 3-phase pressure-temperature equilibrium couples taken from the hydrate stability programme developed by the Colorado School of Mines (CSMHYD) (Sloan 1998) as well as published laboratory measurements (e.g. Dickens and
B
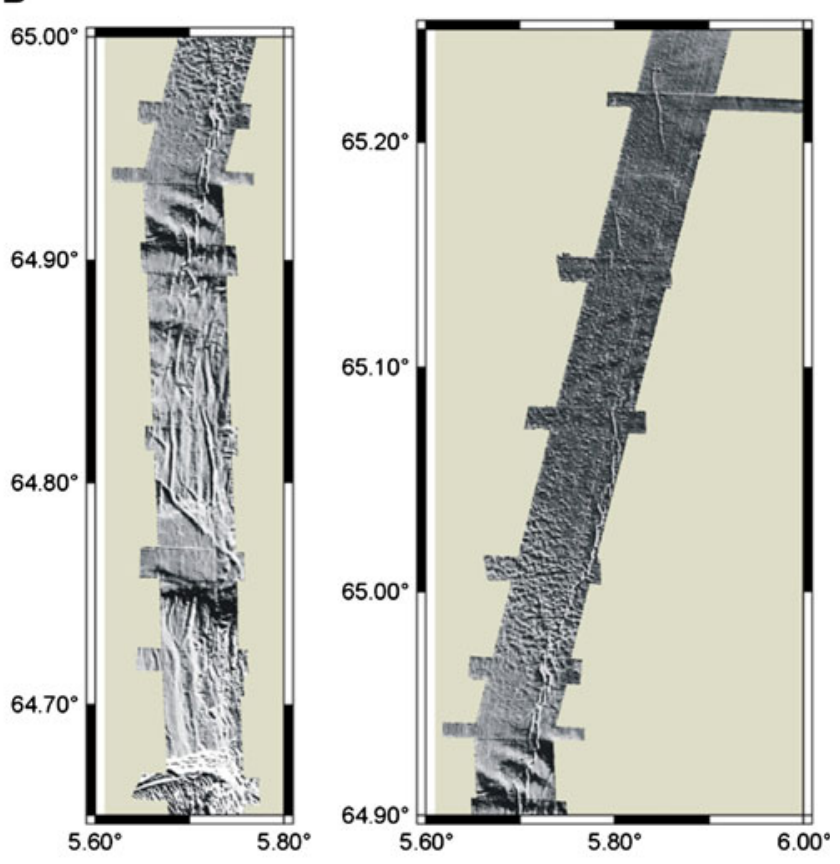

and 792. Gravity core stations 796 and 794, and industry bore hole $6405 / 22$ and heat flow stations are marked. CTD casts were taken at the core stations. Additional gravity cores for age dating were taken by the University of Bergen (see Fig. 4)

Quinby-Hunt 1994). This least square method is valid between $-2^{\circ} \mathrm{C}$ and $25^{\circ} \mathrm{C}$ using a unique triplet $(a, b, c)$ for each gas composition and salinity.

We consider pure methane hydrates in average seawater (35\% salinity). Then, the 3-phase analytical pressure $\left(P_{3}\right.$, scaled in MPa $)$ - temperature $\left(T_{3}\right.$, scaled in $\left.{ }^{\circ} \mathrm{C}\right)$ equilibrium equation can be written as:

$\log P_{3}=a+b \cdot T_{3}+c \cdot T_{3}^{2}$

with $\mathrm{a}=0.478626, \quad \mathrm{~b}=0.040094, \quad \mathrm{c}=0.000309$ and $R^{2}=0.999925$.

For the present, we used the average CTD acoustic velocity to convert water depths to travel times, and additionally, we used the Hamilton sub-bottom velocity function (Hamilton 1980) to relate sub-bottom depths to sub-bottom travel times. Hamilton velocities compare very well with subsurface interval velocities derived from travel time inversion of ocean-bottom seismic data just few km further south (Plaza Faverola et al. 2010).

We used an extensive data set of bottom water temperatures (BWT) provided by the Federal Maritime and Hydrographic Agency (Germany) compiled over the entire North-Atlantic area and filtered these for the area of interest between $0-8^{\circ} \mathrm{E}$ and $62-67^{\circ} \mathrm{N}$. This data set was 

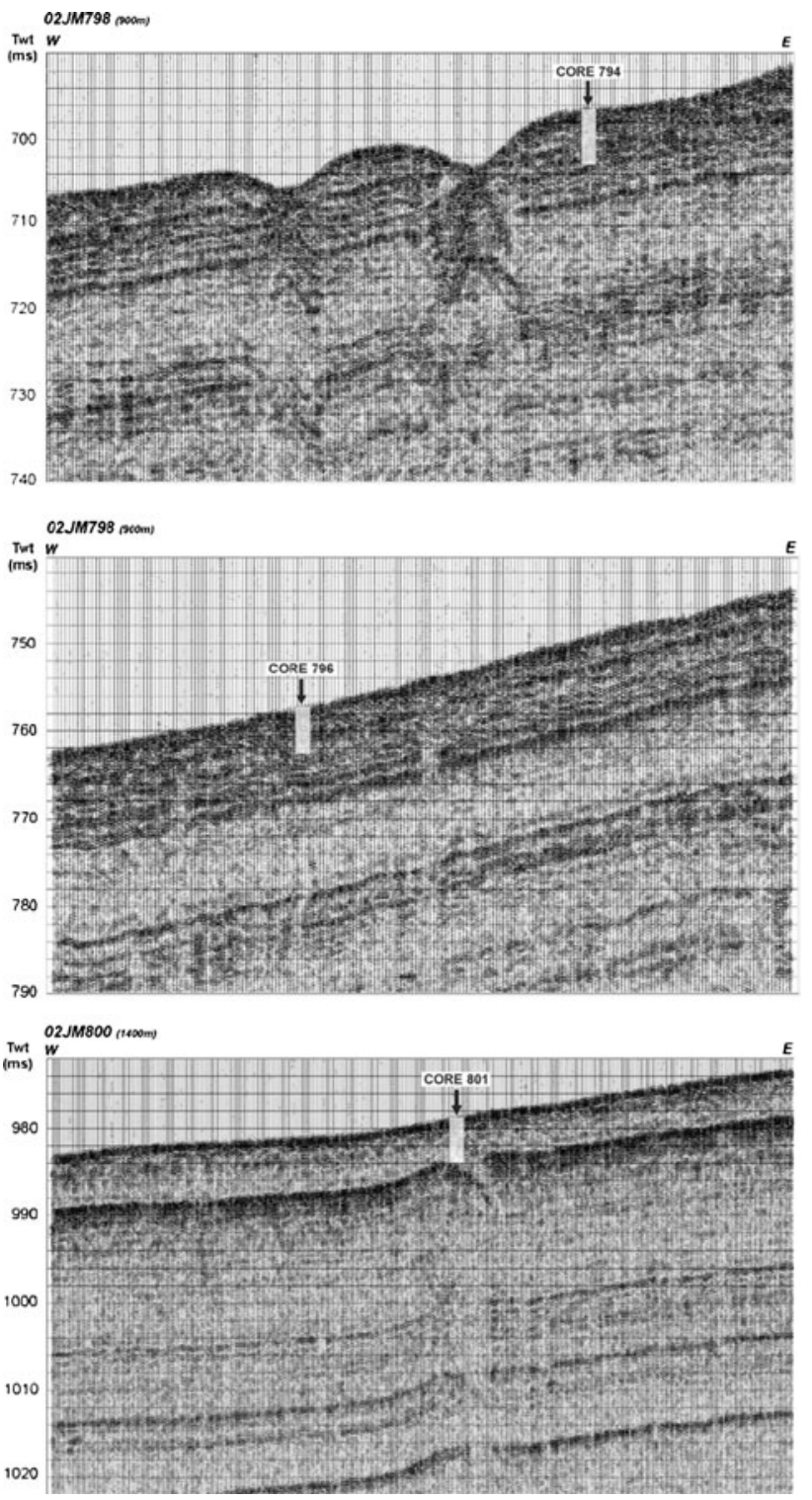

Fig. 4 Gravity core positions projected on $3.5-\mathrm{kHz}$ echosounder profiles. From top to bottom: core 794 ( $540 \mathrm{~m}$ water depth) has a length of $5 \mathrm{~m}$, core 796 ( $\sim 580 \mathrm{~m}$ water depth) has a length of $4 \mathrm{~m}$ and core 801 taken on top of a potential fluid escape feature is $4 \mathrm{~m}$ long (see also Fig. 5)

completed with bottom water temperature information we acquired from CTD casts during recent expeditions in the Storegga Slide area. In total, 130 samples were taken into account. Unfortunately, the data set in the immediate neighbourhood of our seismic data is sparsely distributed with exception of our own CTD temperature measurements; and therefore, two different approaches were used in our modelling exercise.

The first approach consisted of minimum curvature interpolation and gridding this selection of BWT values over the entire area using GMT software (Wessel and Smith 1998).

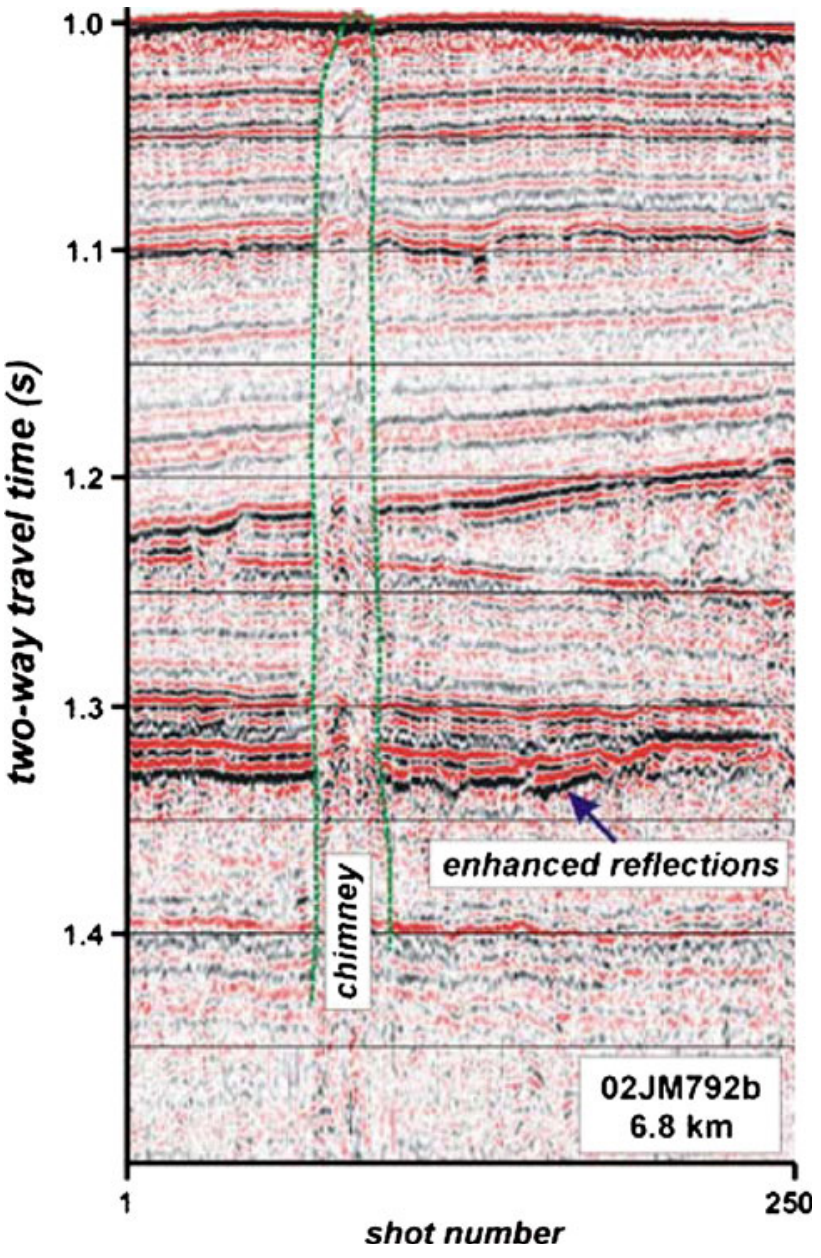

Fig. 5 Seismic line 02JM792b from south (left) to north (right) showing deeper-rooted fluid escape chimneys. Core 801 was taken from the top of the chimney feature (Fig. 4)

The second approach used the BWT measurements selected to make a best-fit BWT curve as a function of water depth (Fig. 7). This best-fit analytical function for the area is then written as follows:

$$
\begin{aligned}
& T_{0}\langle H\rangle= \\
& \begin{cases}8.149175-0.00284 \cdot H-2 e-6 \cdot H^{2} & H \leq 456.6 \\
28.33701-0.06075 \cdot H+2.8 e-5 \cdot H^{2} & 456.7 \leq H \leq 720.6 \\
-0.9 & H \geq 720.6\end{cases}
\end{aligned}
$$

with $H$ water depth (m). In this way, BWT distribution is simply calculated using the above-mentioned formula from the bathymetric data set used. Compared with the two CTD stations, this analytical BWT function gives slightly higher BWT than measured. We note that for these depths the scattering of BWT data is significant and hence, the regression coefficient of the best-fit approaches smaller, contributing to such deviations (Fig. 7).

We suppose that the present-day situation is in thermal equilibrium with a uniform thermal conductivity, thus 
Fig. 6 Seismic line and shaded relief map showing location of cracks, industry bore hole 6405/ 2 and gravity core stations 122 for dating sediment samples from the crack (Fig. 3)

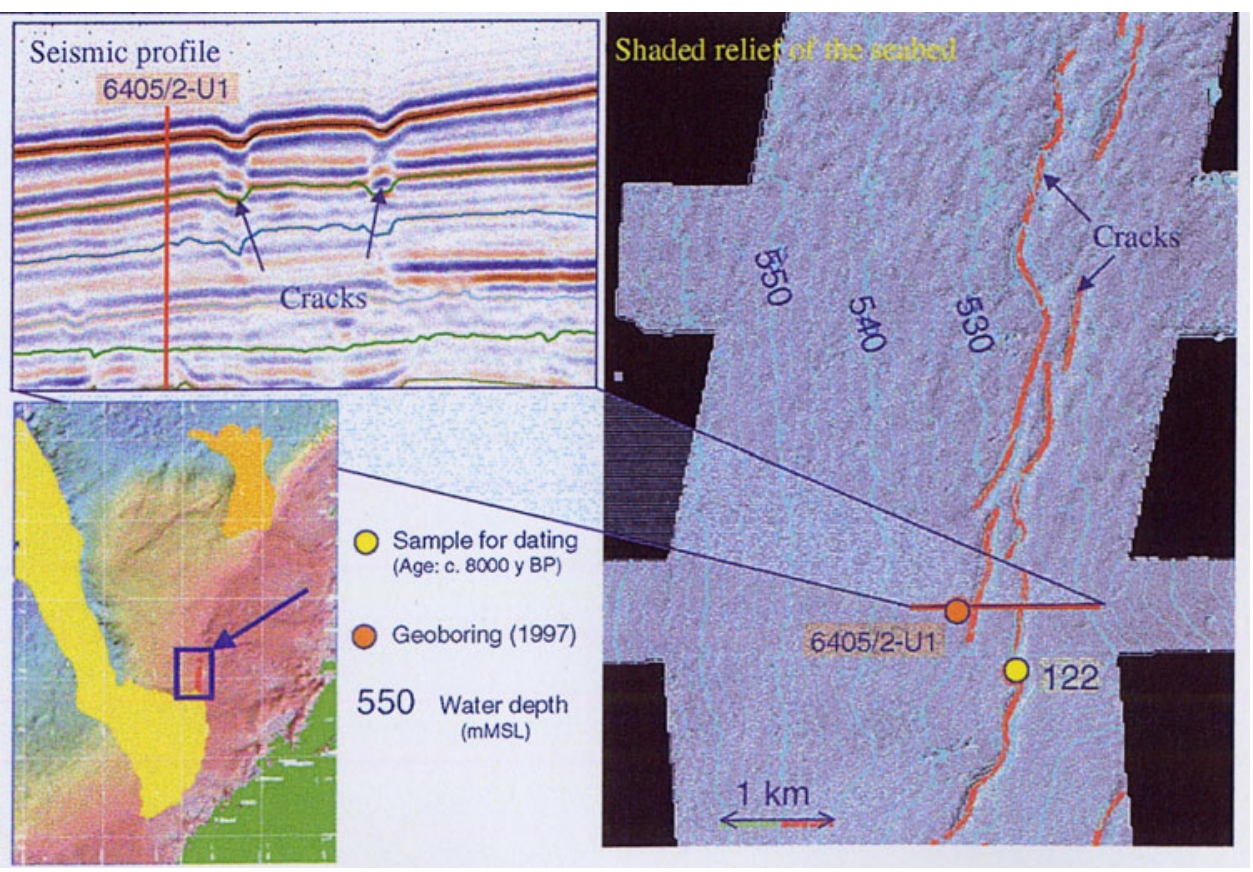

\section{Temperature $\left({ }^{\circ} \mathrm{C}\right)$}

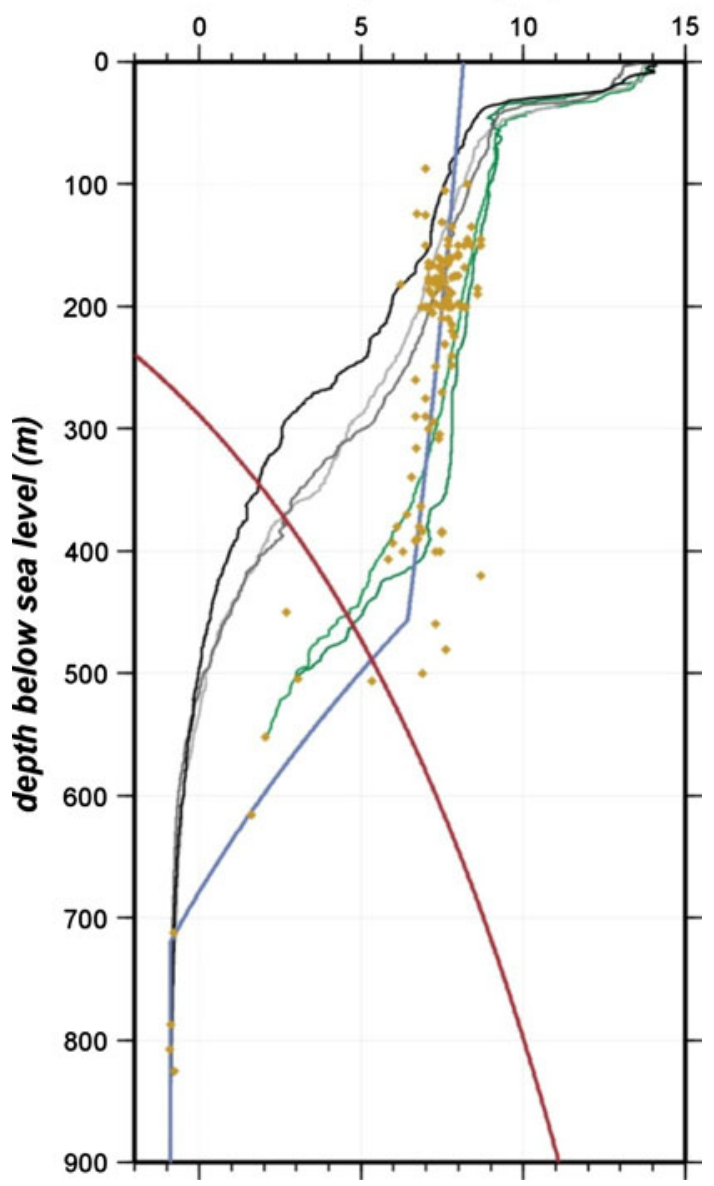

Fig. 7 Bottom water temperature (BWT) data (orange dots), CTD profiles (green - upper slope; grey-lower slope), best-fit temperature subsurface temperature increases linearly with depth. From borehole data (6304/5-GB1A and 6305/2-GB1A at the northern Storegga sidewall), however, we know that this assumption is not fully correct, but we lack more detailed and spatially distributed borehole data to consider this in our modelling. The maximum extent of the bulk hydrate stability field reaches from the seafloor to the intersection of the sub-bottom temperature profile and the 3-phase boundary, i.e. the base of the GHSZ where in situ temperatures exceed hydrate stability temperature, and hence, no hydrates can be stable (Fig. 8).

The evolution of hydrate stability through time, with focus on changes occurring since the LGM, is modelled for a pure conductive, homogeneous and isotropic porous medium on which both sea level changes and bottom water temperature changes are applied. While the former is assumed to be translated immediately through the interconnected pore spaces, the latter needs time before the stability of in situ hydrates is reached. Induced bottom water temperature effects are supposed to occur instantaneously, with full amplitude, taking place at the transition of the Younger Dryas and the Holocene (Jung and Vogt 2004; Mienert et al. 2005). In such case, the situation is reduced to a half-space problem with known (estimated) initial geothermal regime. Solutions of the heat transport equation can then be written in terms of error functions (Carslaw and Jaeger 1959). In addition, we briefly address the subsidence effect of Fennoscandia due to the ice cap loading and the uplift effect of Fennoscandia due to the ice sheet retreat on the continental shelf area off mid-Norway in context with induced changes on the gas hydrate stability 
Fig. 8 Sketch of the hydrate stability field on a pressuretemperature phase diagram (a) and its theoretical extent in continental margin and slope sediments (b)
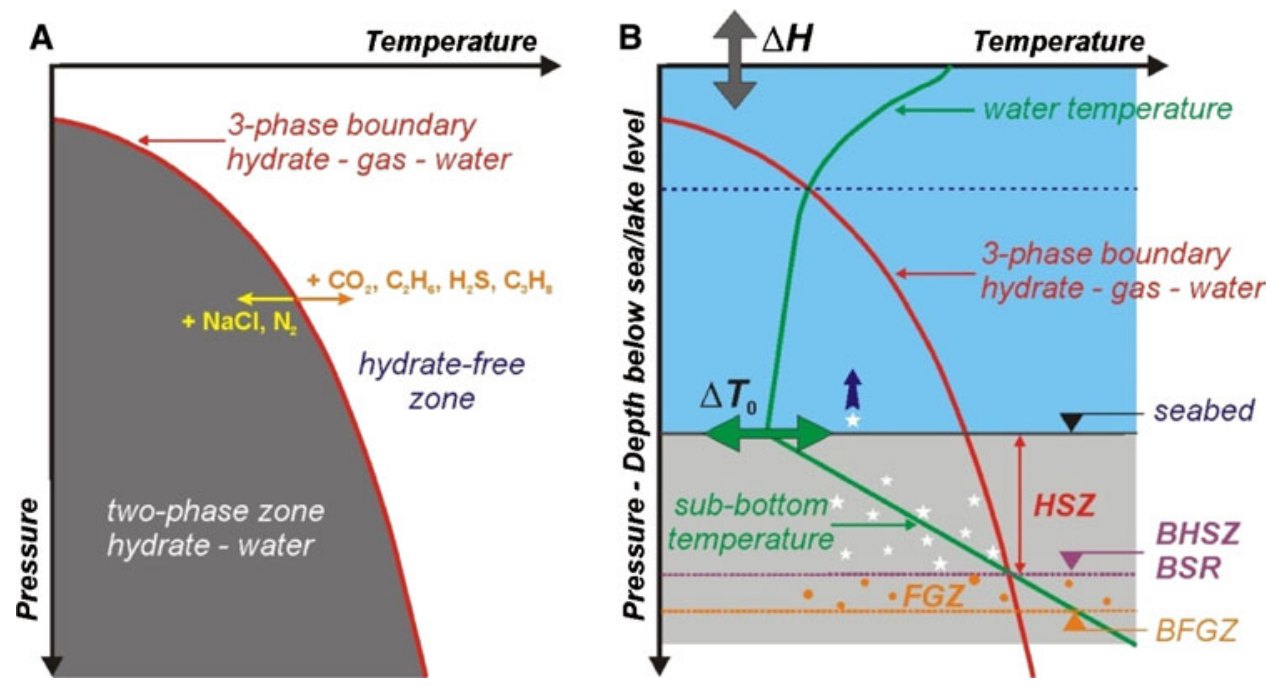

conditions. Due to ice load during glacial and its release during interglacials, in situ pressure and temperature distribution will be altered, and hence, such variation may affect hydrate stability conditions in the shelf areas, where hydrates are not stable at present. However, the limited amount of information available hampers detailed analyses.

We are aware that this methodology simplifies realities, by ignoring convective flow and permeability, capillary effects and sedimentation. Nevertheless, the presence of BSRs close to the study area suggests that the geothermal field is rather uniform, with only marginal fluid flow activity taking place today. The presence of the Nyegga pockmark field demonstrates that fluid seeping takes place locally, penetrating the hydrate stability zone (Mienert et al. 1998, 2001; Bouriak et al. 2000; Bünz et al. 2003; Hustoft et al. 2009b, Plaza Faverola et al. 2010). However, changes in the pore size may change capillary pressures in the sediment. High capillary pressures can cause changes in the temperature/pressure condition (Anderson et al. 2009). Because of the uncertainties in quantifying gas hydrates in the study area since the LGM, we neglect capillary pressures and the latent heat inherent to hydrate dissociation due to warming in our modelling. Since hydrate dissociation is a heat-absorbing reaction, it requires energy for decomposition, thus it will extract heat from the surroundings. This will slow down the thermal equilibration with depth within the hydrated zone. Therefore, the results presented here have to be considered as conservative.

\section{Results}

Seafloor bathymetry and seismic observations

The sediment cracks (grooves) are distinct features on the shaded-relief map (Fig. 3a) and seafloor dip map (Fig. 3b) as well as on seismic reflection profiles (Figs. 6, 9). They occur on the upper part of the mid-Norwegian continental slope in water depths between 400 and $550 \mathrm{~m}$ showing a system of echelon cracks (Figs. 9, 10, 11). The shaded bathymetrical imagery of this area, extending from the Storegga Slide scar in the south and into the pockmarks areas in north, shows the size and quantity of the fractures preserved at the surface (Figs. 3, 11). The crack area is defined by a depression bounded by normal faults.

This approximately 5-km-wide zone of cracks continuous slope parallel (S-N trend) over approximately $60 \mathrm{~km}$ (Fig. 3). The individual cracks are up to $10 \mathrm{~m}$ deep and have their roots at a depth of several tens of metres below the seafloor (Fig. 9). Remarkably, these structures line up surprisingly well with the northern termination of the Storegga Slide headwall in the south (Figs. 10, 11). The cracks are the only irregularities on an otherwise gentle dipping and uniform upper continental slope and outer shelf (Fig. 9). A relationship to deep seated faults is

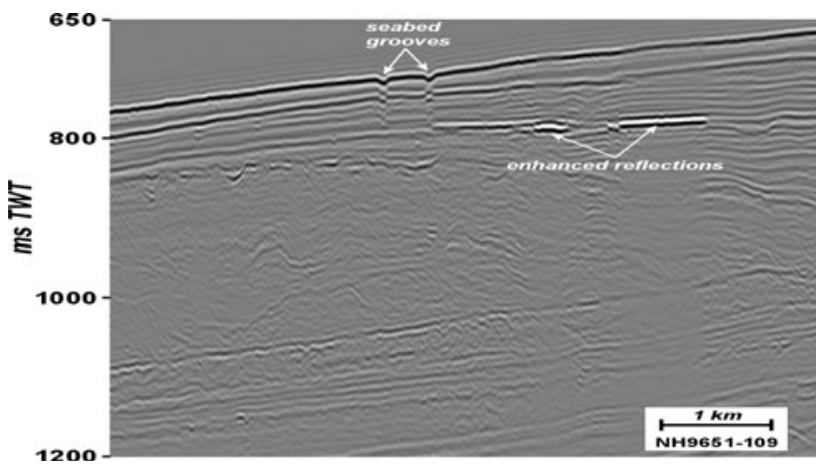

Fig. 9 Seismic line shows seabed cracks that are approx. $10 \mathrm{~m}$ deep and towards the east seismic bright spots (enhanced reflections) with a phase reversal. The bright spots indicate appreciable concentrations of shallow gas (for position see Fig. 3a, dashed line) 
Fig. 10 Example of the seafloor cracking zone extending northward of the northern corner of the Storegga slide (High-resolution sleeve gun seismic data (part of line 02JM670, for location see Fig. 3). Seismic amplitude increases to the left correspond to the base of the hydrate stability zone indicated by the BSR projection (solid line on the lower left between 1.2 and 1.4 TWT)

Fig. 11 Major seabed cracks extending from the northern corner of the Storegga Slide headwall northward (upper inlet Figs. 1, 2). Cracks and pockmarks are observed on a high-resolution shaded relief map of the seabed (upper left). The cracks are approximately $60 \mathrm{~km}$ long (lower overview) and occur in an up to 5-km-wide zone
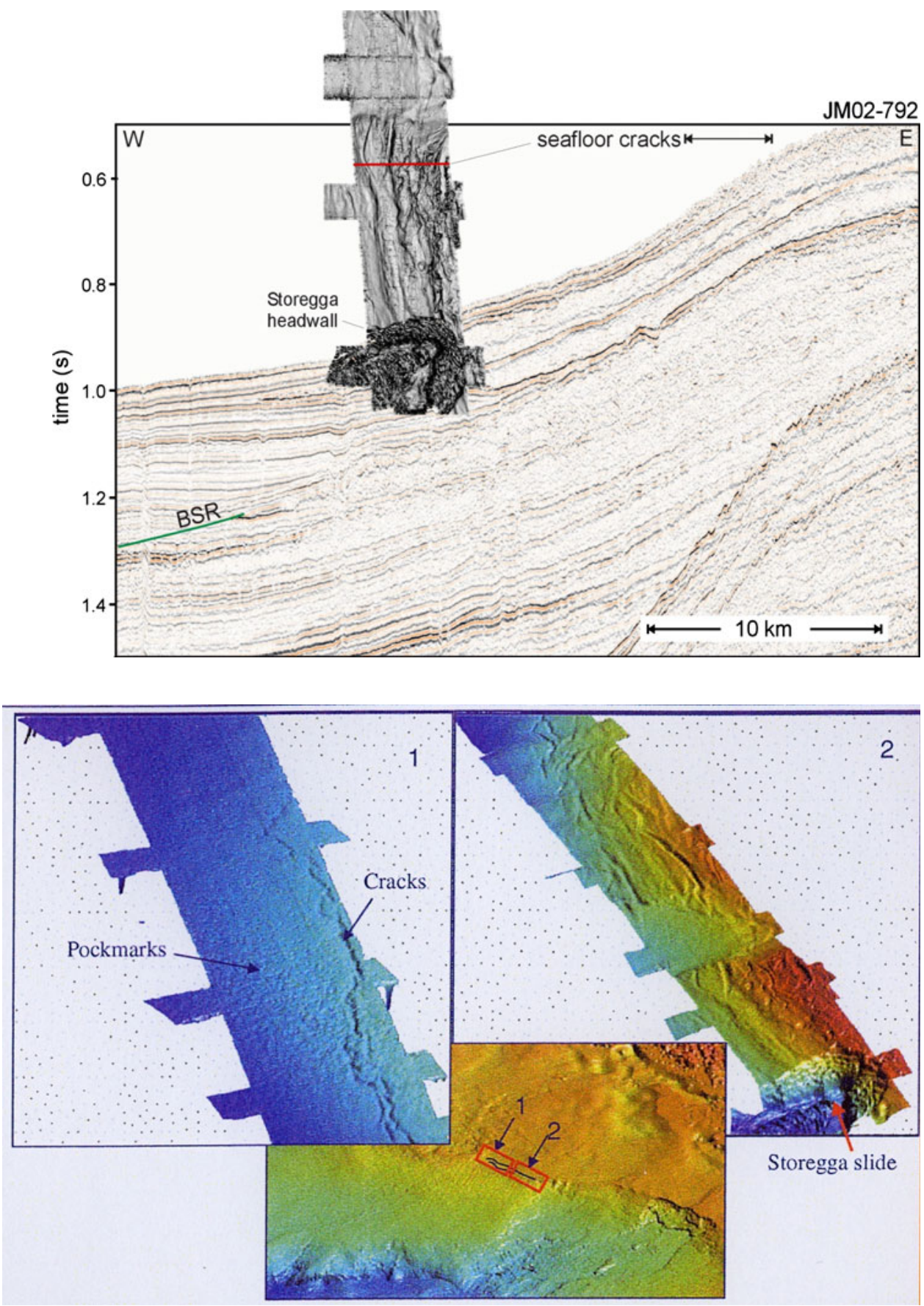

unlikely although it cannot be ruled out completely. Until now, no observation exists that documents a connection between the cracking and fault throw underneath and deep seated faults. However, it may warrant further detailed investigations using high-resolution 3D seismic data.

Fluid-escape features such as surface and buried pockmarks and columnar disturbances of the parallel bedding were previously identified in the crack area (e.g. Fulop 1998; BritSurvey 1999; Mienert and Berg 2002). The seabed in this area is characterised by numerous pockmarks in shallow water on the Trondelag shelf (Fig. 11), typically from 50 to $300 \mathrm{~m}$ wide and 1 to $5 \mathrm{~m}$ deep (Fulop 1998). In the southern shelf area, the pockmark density is estimated to be 15-20 pockmarks per $\mathrm{km}^{2}$ (BritSurvey 1999), and this decreases northwards away from inferred gas hydrate fields (Bünz et al. 2003). At the gas hydrate field on the continental slope, the Nyegga pockmark field shows typically 100-350 m wide and less than 20-m-deep depressions (Hustoft et al. 2009b).

Bright spots identified within the acoustically well-layered deposits occur approximately $600 \mathrm{~m}$ east of the geotechnical borehole location $(6405 / 2)$, indicating the possible 
presence of shallow gas at $\sim 52 \mathrm{mbsf}$ (Figs. 6,9). Along the short N-S trending seismic line $792 \mathrm{~b}$, an acoustic chimney penetrates the seabed in water depths of $745 \mathrm{~m}$ (Fig. 5). The nearly vertical chimney extends through the upper $300-400 \mathrm{~m}$ of sediments and its width is approximately $600 \mathrm{~m}$. This feature significantly disrupts the subsurface stratigraphy, even though some internal reflections can be discerned within this feature. Reflections at the flanks and those faint reflections within the core of this chimney do not show bending or velocity effects. The roots of this feature lie deeper than the regional extent of the gas hydrate stability zone, which lies at $\sim 200 \mathrm{mbsf}$ (Bünz et al. 2003). Therefore, it may serve as an active pathway for deeper fluid migration towards the seafloor. From the $3.5-\mathrm{kHz}$ data (Fig. 4, core 810), we observe that the seafloor is irregular on top and uplifted in a mound-like structure by less than $2 \mathrm{~m}$. This mound appears as a chaotic or transparent zone completely lacking internal reflections on the $3.5-\mathrm{kHz}$ data (Fig. 4). The sediment core from the mound structure is characterised by a complex pattern of small-scale fractures and a concentration of chemosynthetic benthic biota.

Sediment physical properties, X-ray radiographs and the age of cracks

\section{Sediment physical properties}

The undrained shear strength $(\mathrm{Su})$ is shown in Fig. 12 . Standard deviations are shown as error bars in the shear strength profile. The data scattering is more significant in the core from the mound, showing lower shear strength in the top section, but merging with the other cores in the deeper part. Fig. 12 displays both the dry water content (being the ratio of water mass to solid mass) and wet water content (being the ratio of the water mass to bulk soil mass). There are clear differences in water content on the three gravity cores. Obviously, the sediment core from the mound structure has significantly higher water content in the upper 1-2 $\mathrm{m}$, reaching maximum values of $94 \%$ (dry water content) and $48^{\circ}$ (wet water content). This correlates well with the lower shear strength measured in the top part of this core. In the interval between 1.0 and $1.5 \mathrm{mbsf}$, the water content of core 02JM794 is higher than that of core 02JM796. In the lowest part, the water content is variable but comparable from the one core to the other.

\section{$X$-ray radiographs}

Gravity core 801 penetrated a fluid flow-related mound feature (Fig. 4) and is thus described in more detail. As from the sediment physical property results, the core retrieved from the top of a mound structure differs significantly from the other two cores. Upon opening the core,

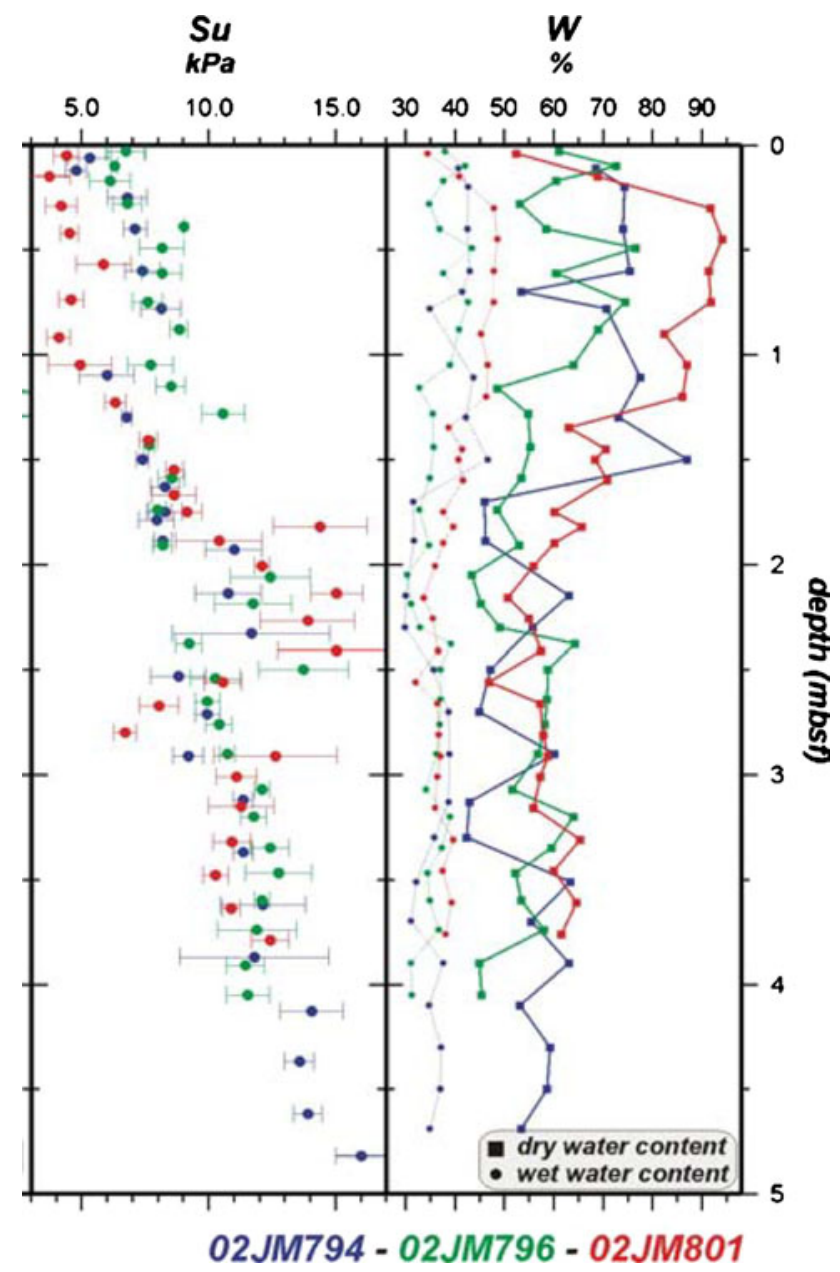

Fig. 12 Sediment core analyses (undrained shear strength $\mathrm{Su}$ and both the dry and wet water content $\mathrm{W}$ ) results from the 3 gravity cores

we immediately smelled $\mathrm{H}_{2} \mathrm{~S}$ and realised the higher water content in the top sediments. In contrast to the other cores, this sediment core ( $>2 \mathrm{mbsf}$ ) is characterised by its abundance in shell fragments, appearing isolated, grouped and concentrated in layers. This is clearly evidenced on the X-ray images (e.g. at $225 \mathrm{cmbsf}$, Fig. 13). The bottom part (>3 mbsf) is more or less free of shells.

The sediment cores reveal distinct differences between the one taken from the mound structure and those from the upper slope part located in the immediate vicinity of the sediment cracking (groove) system. The top layer from the mound structure has very high water content and low undrained shear strength. In the deeper part, however, the differences in these parameters diminish. Shell fragments are only abundant in the core from the top of the mound, suggesting favourable conditions for fluid venting-related communities.

Our results from the two cores from the shelf are in agreement with other logs and analyses on sediment cores from the mid-Norwegian margin (e.g. King et al. 1998; 

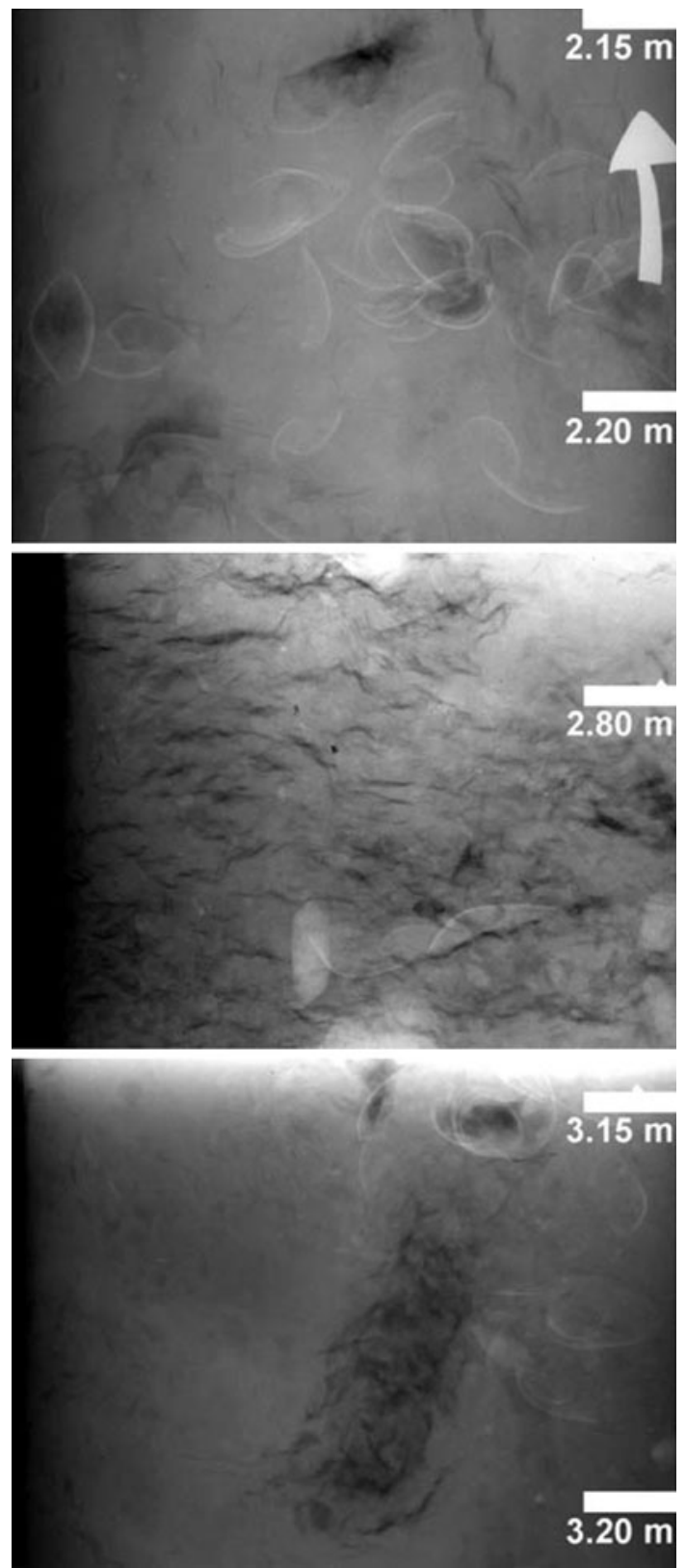

Fig. 13 X-ray photographs (from top to bottom) from core 801 of a cluster of shell fragments, small scale fractures and the co-existence of sediment fractures and shell fragments. The scale is seen on the right given with $5 \mathrm{~cm}$ between white bars

Dahlgren 2002; Dahlgren and Vorren 2003). However, the results from the mud mound added new information to focussed fluid flow regimes in the study area. Undrained shear strength values are low, especially for the top part of the mound structure.

\section{The age of cracks}

Core NH9856 SPB-003SC is located in the open crack area north of the main Storegga Slide headwall, in a water depth of $525 \mathrm{~m}$ (Fig. 6, location 122). The core with the thickest post-crack sediments has been selected for litho-, bio- and chronological studies.

The lower boundary of the post-crack sediments is identified at $122 \mathrm{~cm}$ depth in the core, with aid of both visual description and litho- and foraminiferal stratigraphical (benthic and planktonic) analyses (Fig. 14). The fauna assemblage below this boundary consists entirely of glacial environmental species whereas the fauna assemblage above this boundary is dominated by warm water species with also a substantial amount of cold water species. The cold water species found above the boundary are interpreted to have been reworked from the older strata.

One AMS radiocarbon date are available from the core (Fig. 6). The sample material dated consists of handpicked monospecific planktonic warm water species $N$. pachyderma (dex). The sample comes from the strata boundary identified at 121-122 cm depth where also the warm water planktonic and the benthic species first appear (Fig. 14). The quality of the dating is expected to be good as the analysed sample consists of ca. $8 \mathrm{mg}$ of a pure carbonate foraminifera tests.

The boundary at $121-122 \mathrm{~cm}$ has been dated to $7350 \pm 55{ }^{14} \mathrm{C}$ years BP or 8180 cal years BP, which in turn dates the formation of the crack area that can be traced from the northern Storegga Slide main headwall into this area (Haflidason et al. 2002). It is therefore reasonable to suggest that the crack area is associated with the main Storegga Slide event at $8100 \pm 250 \mathrm{cal}$. BP (Haflidason et al. 2004, 2005). The data available do not show any evidence that the crack area has been reactivated later. Based on the interval dated, the sedimentation rate and the standard deviation, the age error of the base post-slide unit is estimated to be about 150 years.

\section{Gas hydrate stability zone modelling}

The methodology described under 3.4 was first applied for estimating the present-day equilibrium extent of gas hydrate stability along the seismic sections acquired, and afterwards for the glacial gas hydrate stability zone along the upper margin.

Geothermal information from the study area was taken from the HEAT database (Planke 1989). Over the entire study area, the geothermal gradient ranges between a low of 40 and a high of $140^{\circ} \mathrm{C} \cdot \mathrm{km}^{-1}$. In general, geothermal gradient tends to decrease with increasing water depth along the continental slope. The seismic data acquired for this study fall in between of two series of heat flow measurements, and hence, the heat flow values along the seismic data result from interpolation only.

It is important to note that the heat flow or geothermal data from the study area - as extracted from the HEAT data 
Fig. 14 Overview of the bathymetry, sub bottom chirp profile and core stratigraphy from the fracture area north of the Storegga Slide headwall. From top to bottom: (1) bathymetric contour map $(0.5 \mathrm{~m}$ contours) with inserted location of the four studied cores (001004 , see also there position in Fig. 6 named 122), (2) interpretation of Seabed Profile SPB-X with location of cores (001, 002, 003), (3) cross-core correlation and stratigraphic location of the AMS ${ }^{14} \mathrm{C}$ dated sample in core 003 , and (4) chirp profile showing the faults and crack (downthrown block). The core selected for dating was selected due to an expanded stratigraphic section following the creation of the crack. The boundary dated presents a major litho- and biostratigraphical change. The fauna below this boundary consists entirely of glacial environmental species whereas the fauna assemblage above this boundary is dominated by warm water species similar to the faunal assemblage found in a geotechnical boring (Haflidason, 1998). The cores show from left to right grain sizes (black 63-125 $\mu \mathrm{m}$, white 125-500 $\mu \mathrm{m}$, red $>500 \mu \mathrm{m}$ ), water content $(\%)$ and shear strength. The chirp profile, at the bottom, is an expanded part of the fracture zone showing details in the stratigraphy, sediment infilling and the fracture system
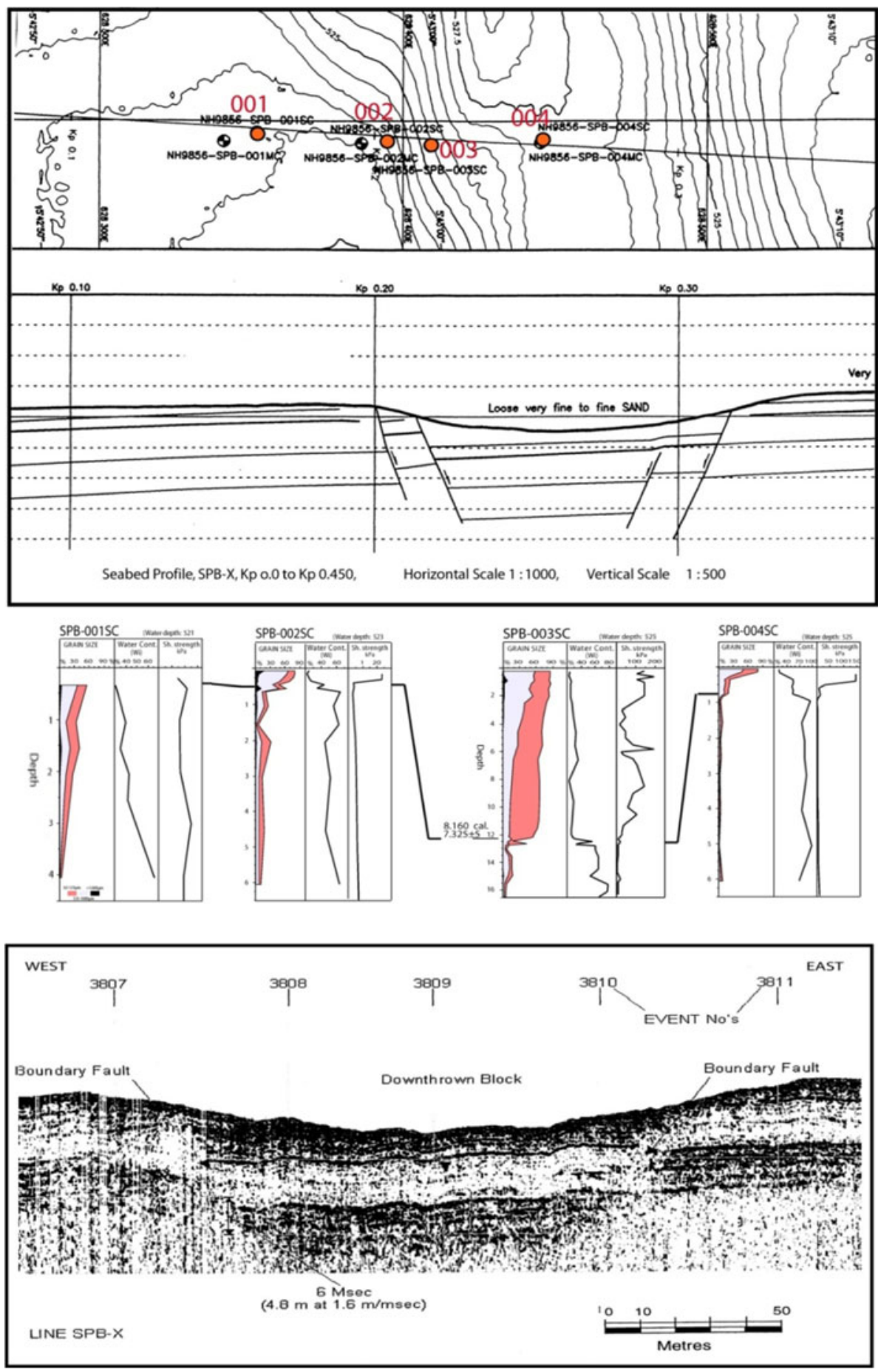

base - is sparsely distributed and in general relatively high. As a result, the gridding procedure gives an elevated geothermal gradient over the entire area. Our modelling is smoothing the anomalies due to the lack of heat flow or geothermal data in the immediate vicinity of the seismic data. There is, unfortunately, no better solution circumventing this problem except doing more heat flow measurements. We also note that the study area lies in a high heat flow anomaly delineated by Sundvor et al. (2000), while the surroundings are characterised by a lower heat flow between 50 and $75 \mathrm{~mW} \cdot \mathrm{m}^{-2}$. Nevertheless, for gas hydrate stability modelling, our predictions based on high heat flow regimes will represent minimum sub-bottom depths where the errors are with a few metres.

A similar methodology was used to invert the sub-bottom depth of the BSR as observed on the seismic data into estimates for the geothermal gradient in every point of observation. Subsequently, the results are compared with 
the geothermal gridded data. In this approach, conversion from the picked two-way travel time scale on the seismic records to depths in $\mathrm{m}$ scale is based on a combination of measurements and empirical relationships. A similar inversion procedure using the methane hydrate phase boundary was applied by Bouriak et al. (2000) on singlechannel seismic reflection profiles acquired at the northern rim of the Storegga Slide area. The authors conclude that a geothermal gradient of 51.5 to $55.8^{\circ} \mathrm{C} \cdot \mathrm{km}^{-1}$ fits best the observed BSR at 250 to $300 \mathrm{mbsf}$ in water depths ranging from 800 to $1250 \mathrm{~m}$. Similar values around $55^{\circ} \mathrm{C} \mathrm{km}^{-1}$ are reported by other authors as well (e.g. Mienert et al. 1998; Andreassen et al. 2003). However, there is a slight discrepancy between inferred geothermal gradients from the BSR depth, and the measurements stored in the HEAT database. For example, inversion along two seismic lines that show a BSR in the deeper part returns inferred geothermal gradients between 50 and $60^{\circ} \mathrm{C} \mathrm{km}^{-1}$, approximately $10^{\circ} \mathrm{C} \mathrm{km}^{-1}$ lower than the values extracted from the geothermal grid, thus modelling uncertainties are given in the positioning of the gas hydrate stability outcrop zone by a few metres.

Figure 15 presents the modelling results of the presentday extent of the hydrate stability zone. It sketches the subbottom depth of hydrate stability using the bottom water temperature grid, and it shows present-day hydrate stability conditions in case of a best-fit bottom water temperature curve with depth. From the figure, it becomes clear that the seabed cracks, as observed from the high-resolution bathymetry data and seismic reflection profiles, match the areas with the present-day limits of hydrate stability on the upper part of the continental slope. Our modelled gas hydrate stability outcrop zones on the Norwegian Margin are well within the previously modelled changes in the upper gas hydrate zone on the Norwegian margin (e.g. Mienert et al. 2001).

For the evolution of the GHSZ since the Last Glacial Maximum (LGM), i.e. combining the effects of both sea level increase and bottom water temperature increase over time, we estimated the gas hydrate outcrop zone in the study area. A simplified example on a section across the mid-Norwegian margin is displayed in Fig. 16. The modelling shows that the hydrate stability zone is reduced from glacial to interglacial conditions for water depths less than approximately $750 \mathrm{~m}$. The shrinking or upward migration of the base of hydrate stability in this part of the slope is dominated by the rising bottom water temperatures. Additionally, we split up this area in a shallow part (between 375 and $525 \mathrm{~m}$ water depths) and a medium part (between 525 and $750 \mathrm{~m}$ water depth). In the shallow part, the migration of the base of hydrate stability would create an outcrop zone over time as a result of increasing bottom temperatures with time. Obviously, the shallower part for
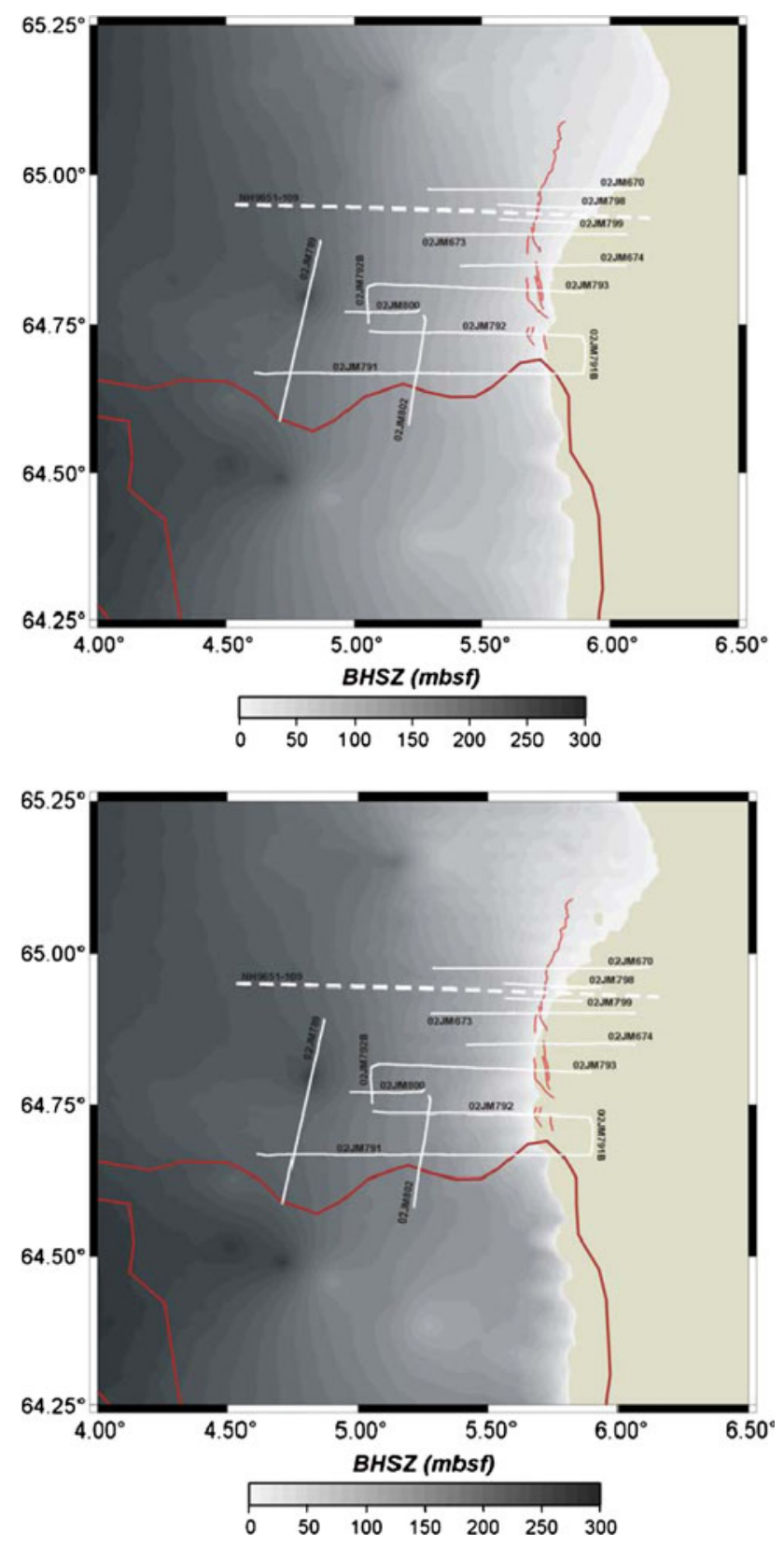

Fig. 15 Present-day limit of the methane hydrate stability zone off mid-Norway, from combining heat flow, ocean temperature and bathymetry data. At the top, we use a minimum curvature interpolation and gridding of bottom water temperatures while at the bottom we use a best-fit of bottom water temperature with water depth, determined from the same set of data points. The thin red lines represent the seabed cracks observed on the high-resolution bathymetry. The resulting uncertainties in the position of gas hydrate stability zone outcrop zones amount to a few metres on the vertical scale. The white lines represent the seismic data. The bold dark red curve is the Storegga Slide scarp. The eastern part indicated by the thin red line falls out of the hydrate stability zone. Due to the elevated heat flow grid, the BHSZ might lie slightly deeper

which hydrate stability changes of several tens of metres are estimated is the most critical one for hydrate stability conditions during climatic cycles. The deeper part, i.e. at 


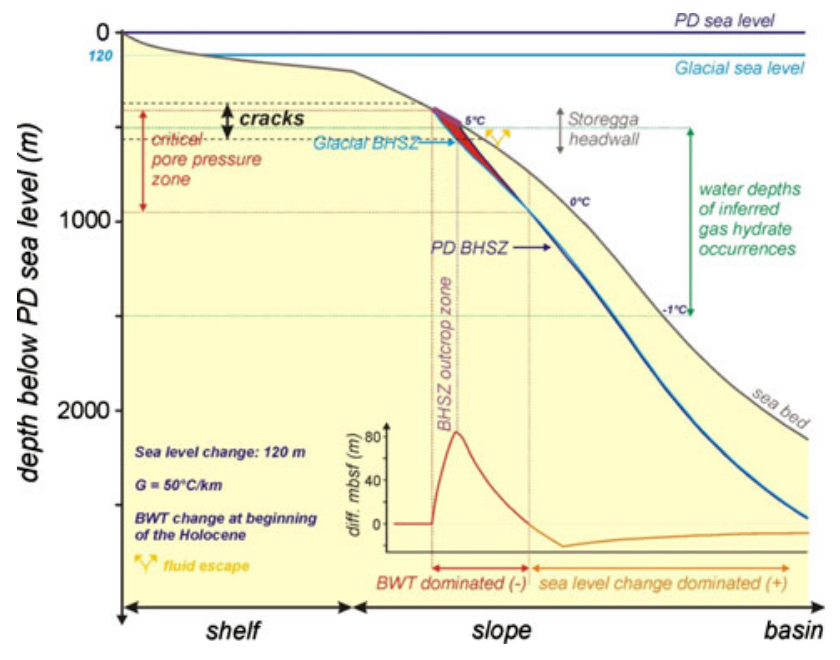

Fig. 16 Evolution of methane hydrate stability conditions across the mid-Norwegian margin since the LGM for a simplified change in bottom water temperatures by $5^{\circ} \mathrm{C}$ combined with a sea level rise of $120 \mathrm{~m}$ (revised after Mienert et al. 2005). We also illustrated the approximate location of the Storegga Slide headwall and the area of inferred gas hydrate occurrences. For water depths less than $950 \mathrm{~m}$, hydrate stability conditions are dominated by the change in bottom temperatures, and hence, will be reduced. This zone is further split up in two areas for where BSR cropped out $(375-525 \mathrm{~m})$ or only migrated upwards without outcropping $(525-950 \mathrm{~m})$. The deeper water areas $(>750 \mathrm{~m})$ evolve towards more favourable hydrate stability conditions, and hence a limited subsidence of the BSR with time. We also indicated the interval where the crack structures are observed (400-550 m water depths)

water depths exceeding $750 \mathrm{~m}$, hydrate stability conditions are controlled by the rise in sea level (pressure increase), as temperature changes are small. As a result, the BSR is slightly deepening over time in the order of metres increasing the hydrate stability zone.

The GHSZ modelling involves an uncertainty that stems from the lack of accurate data about the glacial loading. Over the last ca. 2.6 Ma, the Norwegian continental margin has been affected by several cycles of growth and decay of the Fennoscandian ice sheet (e.g. Vorren et al. 1998; Dowdeswell and Siegert 1999; Sejrup et al. 2000; Dowdeswell et al. 2002; Ottesen et al. 2002; Taylor et al. 2002). This means that the Norwegian continental shelf area has been subjected to both strong sea level changes (as a result of eustatic sea level change and tectonic or isostatic effects) and large-scale ice sheet movement (Dowdeswell et al. 2002). The maximum ice sheet thickness over central Scandinavia is estimated to be about $3.2 \mathrm{~km}$. The shelf area is reported to have had an ice cover of $\sim 600 \mathrm{~m}$ at the coastline, diminishing at the outer shelf (Dowdeswell and Siegert 1999). It is the presence of such an ice cap that resulted in changes of the in situ pressure and temperature profile of the continental shelf sediments, and hence, may affect the theoretical extent of gas hydrate in the presentday shelf and probably upper slope. Therefore, the presence of an ice cap on the shelf area during the LGM should be considered in hydrate stability modelling. In combination with the above-mentioned parameters governing hydrate stability in nature, the accurate modelling of this particular situation including the presence of an ice cap requires accurate knowledge of (1) the ice sheet thickness and its distribution on the continental shelf area at the LGM; (2) the timing of the ice sheet retreat in the study area; (3) the temperature distribution in the shelf sediments during the LGM underneath the glacier; and (4) the isostasy history of the shelf area related to ice sheet loading and retreat.

The grounded ice limit during the LGM in the study area was located close to the shelf break at Møre-Trondelag, and thus the Holocene Storegga Slide headwall. Recent studies revealed that the deglaciation of the outermost midNorwegian shelf was initiated around $16,500{ }^{14} \mathrm{C}$ years BP ( $\sim 20,000$ cal years BP), with the main phase of deglaciation starting at $\sim 15,000{ }^{14} \mathrm{C}$ years $\mathrm{BP}(\sim 18,000 \mathrm{cal}$ years BP). Eventually, the ice sheet retreated to the coastal areas by $12,500{ }^{14} \mathrm{C}$ years $\mathrm{BP}(\sim 15,100$ cal years $\mathrm{BP})$ (Rokoengen et al. 1980; Rokoengen and Frengstad 1999; Dahlgren 2002; Dahlgren and Vorren 2003).

We do not have good constraints on several of the parameters (isostatic subsidence, rebound as a result of ice sheet loading, temperature distribution at the grounded ice limit). Therefore, we can only provide a sketch and a conservative estimate of the potential stability of methane hydrates in the shelf area during the LGM (Fig. 17). Considering temperate glaciers, then the basal temperature will be close to $0^{\circ} \mathrm{C}$, so the sub-surface geothermal gradient will not differ significantly compared to the situation described above (Fig. 17, glacial conditions). As a result, the pressure related to the ice load will account for favourable methane hydrate stability condition in the shelf area, dependent on the thickness of the ice cap (Fig. 17). Our modelling suggests that the hydrate stability limit extends to $\sim 300 \mathrm{~m}$ or $\sim 220 \mathrm{~m}$ sub-bottom depths for a $1000 \mathrm{~m}$ or $600 \mathrm{~m}$ ice load on the shelf, respectively.

As illustrated above, without an ice cap, pure methane hydrates cannot be stable in the shelf sediments during glacial conditions. Our simple modelling reveals that a minimum of $\sim 320 \mathrm{~m}$ ice cap loading is needed before methane hydrate can be stable in the uppermost shelf sediments. Lack of details about both the thickness of the ice cap and its regional distribution makes it impossible to accurately predict the potential distribution of methane hydrates in the upper part, including the sensitive hydrate dissociation area in between the shelf (where ice loading might result in favourable hydrate conditions depending on thickness) and the upper slope (where water depths exceed the critical depth for hydrate stability with prevailing bottom temperatures). Therefore, even with ice cap loading, a 

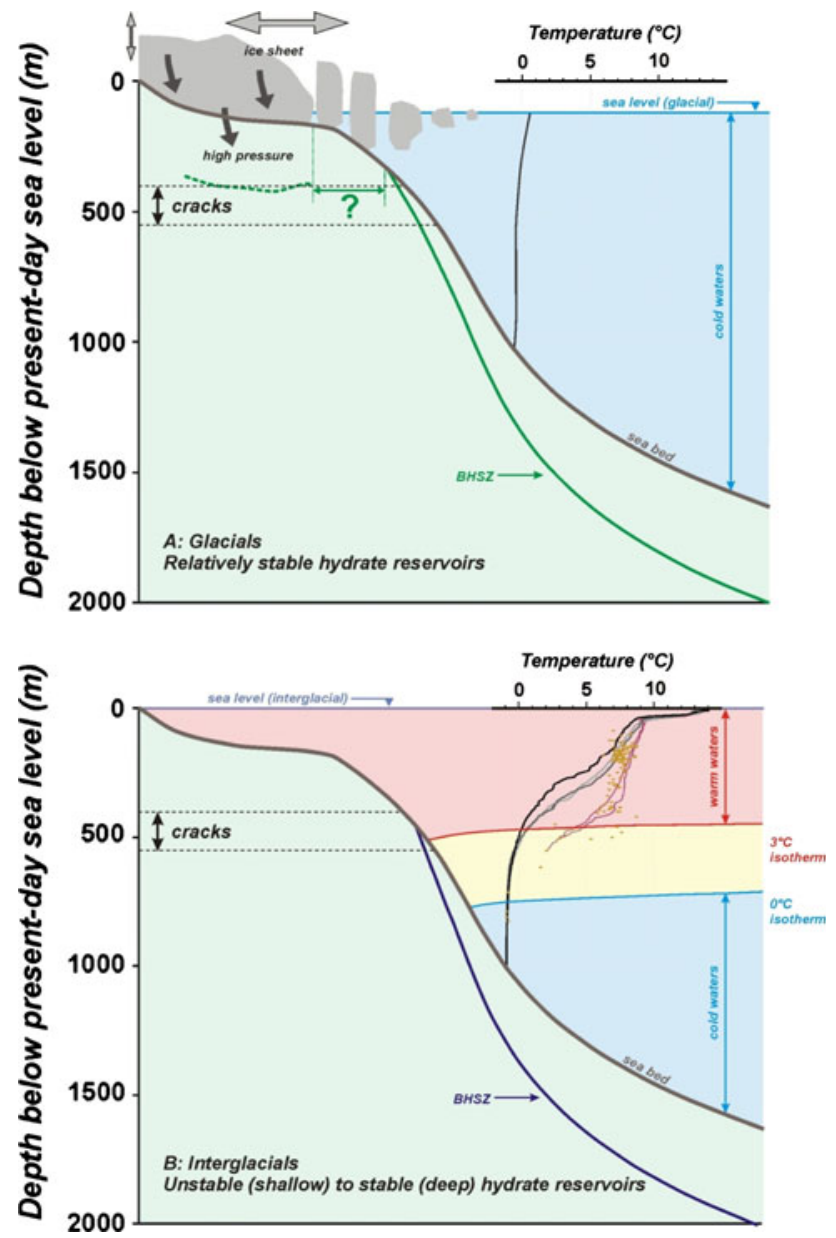

Fig. 17 Sketch and comparison of the methane hydrate stability zone at the LGM including ice sheet loading (not to scale) from the Scandinavian mainland to the continental shelf (a) and the PD (b), similar as the situation above. The ice sheet loading is responsible for a significant vertical stress component in the shelf area, and hence, elevated in situ pressures at glacial times. Supposing temperate glacier conditions, this will result in a methane hydrate stability limit of $\sim 300 \mathrm{~m}$ sub-bottom depth in case of a 1-km-thick ice cap load, as shown in a. We also indicated the interval where the crack structures are observed (400-550 $\mathrm{m}$ water depths)

hydrate-free transition zone between the shelf and upper slope area could have existed during maximum glacial conditions.

\section{Discussion}

The area of potential BSR outcropping during the glacialinterglacial transition lies in water depths between approximately 375 to $525 \mathrm{~m}$, i.e. about the depth range where the sediment cracks are observed north of the Storegga Slide sidewall (Figs. 11, 16-17). Within the uncertainties of BHSZ modelling, the present-day theoretical extent of the gas hydrate stability zone illustrates that the cracks correspond well to the zone where the BHSZ outcrops and intersects the upper continental slope/ shelf, for both approaches (best-fit and interpolated bottomwater temperatures) (Fig. 15). It also follows closely the bathymetric contours on the margin over more than $60 \mathrm{~km}$. The observations indicate that these seabed cracks might result from regional post-glacial gas hydrate destabilization, subsequent pore pressure build-up and gas release from shallow sediments. The exact timing of probable elevated pore pressures from hydrate dissociation is unknown. Modelling results of pore pressure build up in mid-slope sediments in response to high sedimentation rates during LGM suggest fluid expulsion and associated Nyegga pockmark field formation in post-glacial times (Hustoft et al. 2009b). The results are supported by AMS ${ }^{14} \mathrm{C}$ dating of planktonic foraminifera (MDAC and Bathymodiolus clams within pockmarks). The ages range from $\sim 18,000$ to $\sim 13,200$ cal. years BP (Paull et al. 2005). On the shelf and west of the cracking zone, the "Trøndelag pockmark field" most likely also developed in post-glacial times, i.e. after the ice-sheet retreat from the shelf ( $\sim 15,100$ cal years BP) (Rokoengen et al. 1980; Rokoengen and Frestad 1999; Dahlgren 2002; Ottesen et al. 2005). The pockmark development presumably was coeval with the evolution of the cracking or possibly predated it, which suggest active venting between 15.100 cal years BP and the time of the seabed cracking.

The time of the seabed cracking is dated at $7,350{ }^{14} \mathrm{C}$ years BP $(8,180$ cal years BP). This age is also concordant with the formation of the crack area that can be traced from the northern Storegga Slide main headwall into this area (Haflidason 1998). It is therefore a common understanding that the seabed crack area is associated with the main Storegga Slide event that took place at 8,100 \pm 250 cal. years BP (Haflidason et al. 2004, 2005). One could therefore argue that, when failure occurs, lateral stress release may be parallel to the escarpment, which would be perpendicular to the cracks. It can be also suggested that the seabed cracks may be "tension crevices" associated with movements of the Storegga slide although the more than 50-km-long cracks make such a process very unlikely. Glacial retreat and unloading may have caused pore-pressure releases accompanied by fluid-escape and cracking. However, the long time span (approx. 7,000 years) between the ices sheet retreat ( $\sim 15,100$ cal years $\quad$ BP) and the seabed cracking ( $\sim 8180$ cal years BP) makes such a process also very unlikely. Though such processes cannot be completely ruled out at the moment, it would require complex geomechanical modelling incorporating gas hydrate dissociation which is beyond the scope of this paper. Moreover, there is also very little known about the behaviour of gassy soil in terms of inducing cracks and slope failure conditions due to its complexity (Kwon et al. 2008). 
Today's surveyed seabed features on the shelf did not provide evidence for active fluid venting in the study area (gas plumes or bubbles in the water column) but it is suggested that the pockmark field may support ongoing micro seepage. Active venting systems, however, were documented by echo sounder (18 and $38 \mathrm{kHz}$ ) profiling data further north offshore Norway (Chand et al. 2008) in the region outside but very close to the modelled gas hydrate stability field outcrop zone on the Norwegian margin (Mienert et al. 2001). Like in the region further south, deglaciation of the shelf brought this region out of the hydrate stability zone in post-glacial times. Today, several ten-metre-high gas flares indicate methane release from the $<300 \mathrm{~m}$ shallow seabed on the $<50 \mathrm{~km}$ narrow shelf off Vesterålen (Chand et al. 2008). The authors point out that a clear relationship between gas hydrate outcrop zones and gas venting, though likely, cannot be stated because pre-existing and deep-seated faults may have become reactivated in post-glacial times opening pathways for fluid migration.

At the Trøndelag pockmark field, fluid migration to the upper layers appears to be a continuous or episodic process in near vicinity to the cracking of the seabed (Fig. 11). The relatively distinct cracks (Fig. 11) and the widespread pockmark field affect the upper sediments, and it is therefore not unreasonable to suggest that fluid expulsion was a post-glacial or even more recent process north of the Storegga slide. The chimneys (columnar disturbances, Fig. 5) on the continental slope are comparable to those documented by Hovland (1983). Hovland (1981) documented the escape of fluid originating in or below soft clay sequences in the Norwegian Channel, and put forward the hypothesis of seepage from deep-lying hydrocarbon reservoirs. The process involved in the formation of pockmarks on the seabed surface may be linked to both fluid burst from shallow subsurface gas hydrate dissociation and from deep fluid supplies.

The study area hosts also buried pockmarks, covered by undisturbed deposits that represent a stratigraphic position of the paleo-seabed at the time of the process, dated to the late-early Weichselian (Fulop 1998), which may indicate that fluid expulsion occurred in phases.

\section{Conclusions}

The upper slope of the mid-Norwegian margin between 400 and $550 \mathrm{~m}$ water depths is characterised by a remarkable nearly continuous slope-parallel seabed crack system extending over $60 \mathrm{~km}$ in a 5 -km-wide belt. The depth of the individual cracks ranges from a few metres up to $10 \mathrm{~m}$, with increasing amplitude to the south, where these seabed cracks merge with the northern rim of the
Storegga Slide headwall. The seabed cracks may be "tension crevices" associated with movements on the headwall of the Storegga slide, but gas escape or gas blanking found nearby the cracks suggest pore pressure-related processes.

Although direct evidence of gas hydrates in the study area is limited to the continental slope, the location of these cracks on the upper slope and outer shelf fits well the theoretical or modelled outcrop of the present-day limit of hydrate stability zone. Hence, deteriorating hydrate stability conditions in the shallow water areas since the LGM forced by increasing bottom water temperatures and/or retreat of ice sheet may have triggered the formation of these seabed cracks. Pore-pressure build-up and hydraulic fracturing may therefore be subsequently linked to climatecontrolled gas hydrate dissociation.

High-resolution bathymetry maps, single-channel seismic and echosounder data, and previous studies by Fulop (1998) and BritSurvey (1999) provide clear evidence for fluid migration pathways (e.g. pockmarks, chimneys) along the seabed crack system and west of its lateral extension. This would also be anticipated if the cracking system finds its origin in hydraulic fracturing caused by in situ gas hydrate dissociation and/or deeper fluid migration upwards and subsequent pore pressure build-up in upper sediment formations. We did not observe evidence of active fluid escape from the seabed cracks in form of gas flares.

Shallow sediment cores and seismic data reveal evidence for fluid migration. The presence of chimneys penetrating through the uppermost hundreds of metres of sediment (Hustoft et al. 2009b) and gas hydrate sampling (Ivanov et al. 2007; Haflidason et al. 2008) suggests ongoing micro seepage. One sediment core retrieved from such a potential fluid escape structure shows a high abundance of shell fragments connected to fluid flow pathways.

Seabed cracking and/or increased fluid flow expulsion suggest gas hydrate dissociation processes as a consequence of climate change, which leaves fingerprints in upper continental slope and outer shelf sediments.

Acknowledgments We are grateful to the captain, crew and shipboard party of the R/V Jan Mayen Storegga and Nyegga expeditions for their efforts and craftsmanship. We thank the Federal Maritime and Hydrographic Agency (Germany) for providing the bottom water temperature data set used in this study, and the University of Oslo who kindly provided the heat flow data set. We also thank our lab technicians for taking and scanning the X-ray pictures. We also express our gratitude to J.S. Laberg and A. Colpaert for assisting with the core description, S. Guidard for processing the single channel seismic data, and J. Pedersen for merging the Jan Mayen swath bathymetry data. The University of Troms $\varnothing$ acknowledges support by Landmark Graphics via the Landmark University Grant Program. Data gridding and maps were created in GMT software (Wessel and Smith 1998). This work was funded by EC Grant EVK3-CT-19900006 (COSTA project), by Norsk Hydro Grant NHT-B44VK07981_02 (Seabed project), NFR 158733/V30 (Spacoma project) under the ESF-EUROMARGIN program, and NFR Petromaks project 
fluid flow 169514/S30. This paper is a contribution to the NFR Petromaks project "Gas Hydrates on the Norwegian-Barents SeaSvalbard margin" No 175969/S30. This is publication no. 262 of the International Centre for Geohazards.

Open Access This article is distributed under the terms of the Creative Commons Attribution Noncommercial License which permits any noncommercial use, distribution, and reproduction in any medium, provided the original author(s) and source are credited.

\section{References}

Anderson R, Tohidi B, Webber JBW (2009) Gas hydrate growth and dissociation in narrow pore networks: capillary inhibition and hysteresis phenomena. In: Sediment-hosted gas hydrates: new insights on natural and synthetic systems, vol 319. The Geologial Society of London, Special Publications, London, pp 145-159

Andreassen K, Berteussen KA, Sognes H, Henneberg K, Langhammer J, Mienert J (2003) Multicomponent ocean bottom cable data in gas hydrate investigations offshore of Norway. J Geophys Res 108(B8):2399

Berndt C, Bünz S, Mienert J (2003) Polygonal fault systems on the mid-Norwegian margin: a long-term source for fluid flow. In: Van Rensbergen P, Hillis R, Maltman A, Morley C (eds) Origin, processes and effects of subsurface sediment mobilization ton reservoir to regional scale. Geological Society of London, Special Publications, London, pp 283-290

Bouriak S, Vanneste M, Saoutkine A (2000) Inferred gas hydrates and clay diapirs near the Storegga Slide on the southern edge of the Vøring Plateau, offshore Norway. Mar Geol 163:125-148

BritSurvey (1999) Seabed project: geological and geophysical interpretation in Møre/Vøring area-phase III. Report number: SP-16-BS-01R-00000-99

Bryn P, Østmo SR, Lien R, Berg K, Tjelta TI (1998) Slope stability in the deep-water areas off Mid-Norway. OTC paper 8640, 1998 Offshore technology conference, Houston, Texas

Bryn P, Solheim A, Berg K, Lien R, Forsberg CF, Haflidason H, Ottesen D, Rise L (2003) The Storegga Slide complex: repeated large scale sliding in response to climatic cyclicity. In: Locat J, Mienert J (eds) Submarine mass movements and their consequences, pp 215-222

Bryn P, Berg K, Solheim K, Kvalstad TJ, Forsberg CF (2005) Explaining the Storegga Slide. Mar Petrol Geol 22:11-19

Bugge T (1983) Submarine slides on the Norwegian continental margin with special emphasis on the Storegga area, vol 110. IKU publication, p 152

Bünz S, Mienert J (2004) Acoustic imaging of gas hydrate and free gas at the Storegga Slide. J Geophys Res 109:B04102. doi: 10.1029/2003JB002863

Bünz S, Mienert J, Berndt C (2003) Geological controls on the Storegga gas-hydrate system of the mid-Norwegian margin. Earth Planet Sci Lett 209(3-4):291-307

Bünz S, Mienert J, Andreassen K (2009) Multicomponent seismic studies of the gas-hydrate system at the Storegga slide. In: Collett T, Johnson A, Knapp C, Boswell R (eds) Natural gas hydrates-energy resource potential and associated geological hazards. AAPG Memoir 89:451-466

Canals M, Lastras G, Urgeles R, Casamor JL, Mienert J, Cattaneo A, De batist M, Haflidason H, Imbo Y, Laberg JS, Locat J, Long D, Longva O, Masson DG, Sultan N, Trincardi F, Bryn P (2004) Slope failure dynamics and impacts from seafloor and shallow sub-seafloor geophysical data: case studies from the COSTA project. Mar Geol 213:9-72
Carslaw HS, Jaeger JC (1959) Conduction of heat in solids. Oxford University Press, Oxford, p 510

Chand S, Rise L, Bellec V, Dolan M, Bøe R, Thorsnes T (2008) Active venting system offshore Norway. EOS Trans AGU 89(29):261-262

Dahlgren TKI (2002) Late Cenozoic evolution, sedimentary environment and processes on the mid-Norwegian continental margin. Unpublished Ph.D. thesis, Department of Geology, University of Troms $\varnothing$, Norway

Dahlgren KIT, Vorren TO (2003) Sedimentary environment and glacial history during the last $40 \mathrm{ka}$ of the Vøring continental margin, mid-Norway. Mar Geol 193:93-127

Dickens GD, Quinby-Hunt MS (1994) Methane hydrate stability in seawater. Geophys Res Lett 21(19):2115-2118

Dowdeswell JA, Siegert MJ (1999) Ice-sheet numerical modeling and marine geophysical measurements of glacier-derived sedimentation on the Eurasian Arctic continental margins. Geol Soc Am Bull 111(7):1080-1097

Dowdeswell JA, Cofaigh CO, Taylor J, Kenyon NH, Mienert J, Wilken M (2002) On the architecture of high-latitude continental margins: the influence of ice-sheet and sea-ice processes in the Polar North Atlantic. In: Dowdeswell JA, Cofaigh CO (eds) Glacier-influenced sedimentation on high-latitude continental margins, vol 203. Geological Society Special Publication, London, pp 33-54

Driscoll N, Weissel WJK, Goff JA (2000) Potential for large-scale slope failure and tsunami generation along the U.S. mid Atlantic coast. Geology 28:407-410

Evans D, King EL, Kenyon NH, Brett C, Wallis D (1996) Evidence for long-term instability in the Storegga Slide region off Western Norway. Mar Geol 130:281-292

Fulop A (1998) A seismostratigraphic study of the Late Quaternary sediments, north-east of the Storegga slide area, off mid Norway. Unpublished master thesis, University of Wales, Bangor, $60 \mathrm{pp}$

Gravdal A, Haflidason H, Evans D (2003) Seabed and subsurface features on the Southern Vøring Plateau and Northern Storegga Slide escarpment. In: Mienert J, Weaver P (eds) European margin sediment dynamics: side-scan sonar and seismic images. Springer, Berlin, pp 111-118

Haflidason H (1998) Lithological and chronological analyses of geotechnical borings. Department of Geology, University of Bergen, Norsk Hydro Report, SP-22-UB-01R-00000-98 (1820)

Haflidason H, Sejrup HP, Nygård A, Berstad I, Knorr G (2000) Late Cenozoic evolution and stability of the Storegga region. (Annual Report to Norsk Hydro A/S) Report No. 100-05/00, Department of Geology, University of Bergen, Bergen, $39 \mathrm{pp}$

Haflidason H, Lekens W, Hjønnevåg M, Kristensen K-K, Nygård A (2002) Dating of the Storegga Slide: summary report to Norsk Hydro ASA. Report 100-10/02, Department of Geology, University of Bergen, Bergen, $275 \mathrm{pp}$

Haflidason H, Sejrup HP, Nygård A, Mienert J, Bryn P, Lien R, Forsberg CF, Berg K, Masson D (2004) The Storegga Slide: architecture, geometry and slide-development. Mar Geol 213:201-234

Haflidason H, Lien R, Sejrup HP, Forsberg CF, Bryn P (2005) The dating and morphometry of the Storegga Slide. Mar Petrol Geol 22:123-136

Haflidason H, Hjelstuen BO, Monsen S, Ekerhovd M, Skaug MB, Alvheim S, Vaular EN, Chend Y, Steen IH, Daae F-L, Todt C (2008) Marine Geological Cruise report from the Vøring Plateau. Report no. 100-08/03, Department of Earth Science, University of Bergen, Norway, $37 \mathrm{pp}$

Hamilton EL (1980) Geo-acoustic modelling of the seafloor. J Acoust Soc Am 68(5):1313-1340

Henriet JP, Mienert J (1998) Gas hydrates-relevance to world margin stability and climate change, Geological Society Special Publication no. 137, The Geological Society, London, 333 pp 
Hill JC, Driscoll NW, Weissel JK, Goff JA (2004) Large scale elongated gas blowouts along the U.S. Atlantic margin. J Geophys Res 109:B9. doi:10.1029/2004JB002969

Hjelstuen BO, Sejrup HP, Haflidason H, Berg K, Bryn P (2004) Neogene and Quaternary depositional environments on the Norwegian continental margin, $62^{\circ} \mathrm{N}-68^{\circ} \mathrm{N}$. Mar Geol 213:257276

Hjelstuen BO, Sejrup HP, Haflidason H, Nygård A, Ceramicola S, Bryn P (2005) Late Cenozoic glacial history and evolution of the Storegga Slide area and adjacent slide flank regions, Norwegian continental margin. Mar Petrol Geol 22:57-69

Hjelstuen BO, Haflidason H, Sejrup HP, Nygård A (2009) The Nyegga Pockmark Field on the NE Atlantic margin - a natural laboratory for studies of seepages, their sedimentary environments and development. Geo Mar Lett (in press)

Hovland M (1981) Characteristics of pockmarks in the Norwegian Trench. Mar Geol 39:103-117

Hovland M (1983) Elongated depressions associated with pockmarks in the western slope of the Norwegian Trench. Mar Geol 51:3546

Hovland M, Svensen H, Forsberg C-F, Johansen H, Fichler C, Fossa J-H, Jonsson R, Rueslåtten H (2005) Complex pockmarks with carbonate-ridges off mid-Norway: products of sediment degassing. Mar Geol 218:191-206

Hustoft S, Mienert J, Bünz S, Nouzé H (2007) High-resolution 3Dseismic data indicate focused fluid migration pathways above polygonal faults systems of the mid-Norwegian margin. Mar Geol 245:89-106

Hustoft S, Bünz S, Mienert J, Chand S (2009a) Gas hydrate reservoir and active methane-venting province in sediments on $<20 \mathrm{Ma}$ young oceanic crust in the Fram Strait, offshore NW-Svalbard. Earth Planet Sci 284:12-24

Hustoft S, Dugan B, Mienert J (2009b) Effects of rapid sedimentation on developing the Nyegga pockmark-field, constraints from hydrological modeling and 3D seismic data, offshore mid-Norway. Geochem Geophys Geosyst. doi:10.1029/2009GC002409

Ivanov M, Westbrook GK, Blinova V, Kozlova E, Mazzini A, Nouzé H, Minshull TA (2007) First sampling of gas hydrate from the Vøring Plateau. EOS Trans AGU 88(19):209-216

Jung WY, Vogt PR (2004) Effects of bottom water warming and sea level rise on holocene hydrate dissociation and mass wasting along the Norwegian-Barents Continental Margin. J Geophys Res. doi:10.1029/2003JB002738

King EL, Haflidason H, Sejrup HP, Løvlie R (1998) Glacigenic debris flows on the North Sea Trough Mouth Fan during ice stream maxima. Mar Geol 152:217-246

Knies J, Damm E, Gutt J, Mann U, Pinturier L (2004) Near-surface hydrocarbon anomalies in shelf sediments off Spitsbergen: evidence for past seepages. Geochem Geophys Geosyst. doi: 10.1029/2003GC000687

Kwon TH, Cho GC, Santamarina JC (2008) Gas hydrate dissociation in sediments: pressure-temperature evolution. Geochem Geophys Geosyst 9:Q03019. doi:10.1029/2007GC001920

Laberg JS, Vorren T, Mienert J, Haflidason H, Bryn P, Lien R (2003) Preconditions leading to the holocene Trænadjupet Slide offshore Norway. In: Locat J, Mienert J (eds) Submarine mass movements and their consequences. Kluwer, Dordrect, pp 247254

Laberg JS, Guidard S, Mienert J, Vorren TO, Haflidason H (2007) Morphology and morphogenesis of a high-latitude canyon; the Andøya Canyon, Norwegian Sea. Mar Geol 246:68-85

Locat J, Mienert J (2003) Submarine mass movements and their consequences. Kluwer, Dordrecht, p 538

Lundin E, Doré AG (2002) Mid-Cenozoic post-breakup deformation in the 'passive' margins bordering the Norwegian-Greenland Sea. Mar Petrol Geol 19:79-93
Mazzini A, Svensen H, Hovland M, Planke S (2006) Comparison and implications from strikingly different authigenic carbonates in a Nyegga complex pcokmark, G11, Norwegian Sea. Mar Geol 231:89-102

Mienert J (2004) COSTA — continental slope stability: major aims and topics. Mar Geol 213:1-7

Mienert J (2009) Methane hydrate and submarine slides. In: Steele $\mathrm{JH}$, Turekian KK, Thorpe SA (eds) Encyclopedia of ocean sciences, 2nd edn. Elsevier Ltd, Oxford. doi:10.1016/B978012374473-9.00704-9

Mienert J, Berg K (2002) Destabilisation of gas hydrates as a potential triggering mechanism-what do we model and what do we observe? Ormen Lange-workshop on slope stability and submarine slides, Losby Gods, Norway, 12-13 March

Mienert J, Weaver PP (2003) European margin sediment dynamics: side-scan sonar and seismic images. Springer, Berlin, p 309

Mienert J, Posewang J, Baumann M (1998) Gas hydrates along the north-eastern Atlantic Margin: possible hydrate bound margin instabilities and possible release of methane. In: Henriet J-P, Mienert J (eds) Gas hydrates: relevance to world margin stability and climatic change. Geological Society of London, Special Publication, London, pp 275-291

Mienert J, Posewang J, Lukas D (2001) Changes in the hydrate stability zone on the Norwegian margin and their consequences oceanosphere. In: Schlaefer P, Ritzrau W, Schlueter W, Thiede J (eds) The Northern North Atlantic: a changing environment. Springer, Berlin, pp 259-280

Mienert J, Vanneste M, Bünz S, Andreassen K, Haflidason H, Sejrup H-P (2005) Ocean warming and gas hydrate stability on the midNorwegian margin at the Storegga Slide. Mar Petrol Geol 22:233-244

Ottesen D, Dowdeswell JA, Rise L, Rokoengen K, Henriksen S (2002) Large-scale morphological evidence for past ice-stream flow on the mid-Norwegian continental margin. In: Dowdeswell JA, Cofaigh CO (eds) Glacier-influenced sedimentation on highlatitude continental margins, vol 203. Geological Society, Special Publication, London, pp 245-258

Ottesen D, Dowdeswell JA, Rise L (2005) Submarine landforms and the reconstruction of fast-flowing ice streams within a large Quaternary ice sheet: the 2500-km-long NorwegianSvalbard margin $\left(57^{\circ}-80^{\circ} \mathrm{N}\right)$. Geol Soc Am Bull 117:10331050

Paull CK, Ussler W, Holbrook WS, Hill TM, Keaten R, Mienert J, Haflidason H, Johnson JE, Winters WJ, Lorenson TD (2005) Origin of pockmarks and chimney structures on the flanks of the Storegga Slide, offshore Norway. Geo Mar Lett. doi: 10.1007/s00367-007-0088-9

Planke S (1989) HEAT — a heat flow data base program. Marine and Applied Geophysics Research Group, Department of Geology, University of Oslo, Oslo

Plaza Faverola A, Bünz S, Mienert J (2010) Fluid distributions inferred from $\mathrm{p}$-wave velocity and reflection seismic amplitude anomalies beneath the Nyegga pockmark field of the midNorwegian margin. Mar Petrol Geol 27(1):46-60

Rise L, Ottesen D, Longav O, Solheim A, Andersen ES, Ayers S (2006) The Sklinnadjupet Slide and its relation to the Elsterian glaciation on the mid-Norwegian margin. Mar Petrol Geol 23:569-583

Rokoengen K, Frengstad B (1999) Radiocarbon and seismic evidence of ice-sheet extent and the last deglaciation on the midNorwegian continental shelf. Norsk Geologisk Tidsskrift 79:129-132

Rokoengen K, Gunleiksrud T, Lien R, Løfaldi M, Rise L, Sindre E, Vigran JO (1980) Shallow geology on the continental shelf off Møre and Romsdal, vol 105. Inst Kontinentalsokkelunders, Trondheim, 49 pp 
Rokoengen K, Rise L, Frenstad B, Gustavsen B, Nygaard E, Sættem J (1995) Upper Cenozoic stratigraphy on the mid-Norwegian continental shelf. Norsk Geologisk Tidsskrift 75(2-3):88-104

Sejrup HP, Larsen E, Landvik J, King EL, Haflidason H, Nesje A (2000) Quaternary glaciations in southern Fennoscandia: evidence from southwestern Norway and the northern North Sea region. Quat Sci Rev 19:667-668

Skogseid J, Planke S, Faleide JI, Pedersen T, Eldholm O, Neverdal F (2000) NE Atlantic continental rifting and volcanic margin formation. In: Nøttvedt A (ed) Dynamics of the Norwegian margin. Geological Society of London, Special Publication, London, pp 295-326

Sloan EDJ (1998) Clathrate hydrates of natural gases. Marcel Dekker Inc., New York, p 705

Solheim A, Berg K, Forsberg CF, Bryn P (2005) The Storegga Slide complex: repetitive large scale sliding with similar cause and development. Mar Petrol Geol 22:97-107

Sundvor E, Eldholm O, Gladczenko TP, Planke S (2000) The Norwegian-Greenland sea thermal field. In: Nøttvedt A (ed) Dynamics of the Norwegian margin. Geological Society of London, Special Publication, London, pp 397-410

Talwani M, Eldholm O (1977) Evolution of the Norwegian-Greenland Sea. Geol Soc Am Bull 88:969-999

Taylor J, Dowdeswell JA, Siegert MJ (2002) Late Weichselian depositional processes, fluxes, and sediment volumes on the margins of the Norwegian Sea $\left(62-75^{\circ} \mathrm{N}\right)$. Mar Geol 188(1-2):61-77
Vanneste M, Guidard S, Mienert J (2005) Bottom-simulating reflections and geothermal gradients across the Svalbard margin. Terra Nova. doi:10.1111/j.1365-3121.2005.00643.x

Vorren TO, Laberg JS, Blaume F, Dowdeswell JA, Kenyon NH, Mienert J, Rumohr J, Werner F (1998) The NorwegianGreenland Sea continental margins: morphology and late quaternary sedimentary processes and environment. Quat Sci Rev 17(1-3):273-302

Wessel P, Smith WHF (1998) Improved version of the generic mapping tools released. EOS Trans Am Geophys Union 79:579

Westbrook GK, Chand S, Rossi G, Long C, Bünz S, Camerlenghi A, Carcione JM, Dean S, Foucher JP, Flueh E, Gei D, Haake RR, Madrusaani G, Mienert J, Minshull TA, Houzé H, Peacock S, Reston TJ, Vanneste M, Zillmer M (2008) Estimation of gas hydrate concentration from multi-component seismic data at sites on the continental margins of NW Svalbard and the Storegga region of Norway. Marine and Petroleum Geology 25:744-758

Westbrook GK, Thatcher KE, Rohling EJ, Piotrowski AM, Paelike H, Osbourne AH, Nisbet EG, Minshull TA, Lanoiselle M, James RH, Huehnerbach V, Green D, Fisher EF, Crocker AJ, Chabert A, Bolton CT, Beszczynska-Möller A, Berndt C, Aquilina A (2009) Escape of methane gas from the seabed along the West Spitsbergen continental margin. Geophys Res Lett 36:L15608. doi:10.1029/2009GL039191 